\title{
Synthesis and biological evaluation of hybrid quinolone-based quaternary ammonium antibacterial agents
}

\section{Fedorowicz, Joanna}

2019-10-01

Fedorowicz , J , Saczewski , J , Konopacka , A , Waleron , K, Lejnowski , D , Ciura , K , Tomasic , T , Skok , Z, Savijoki , K, Morawska , M , Gilbert-Girard , S \& Fallarero , A 2019 ,

' Synthesis and biological evaluation of hybrid quinolone-based quaternary ammonium antibacterial agents ' , European Journal of Medicinal Chemistry , vol. 179 , pp. 576-590 . https://doi.org/10.1016/j.ej

http://hdl.handle.net/10138/332221

https://doi.org/10.1016/j.ejmech.2019.06.071

cc_by_nc_nd

acceptedVersion

Downloaded from Helda, University of Helsinki institutional repository.

This is an electronic reprint of the original article.

This reprint may differ from the original in pagination and typographic detail.

Please cite the original version. 


\title{
Synthesis and biological evaluation of hybrid quinolone-based quaternary ammonium antibacterial agents
}

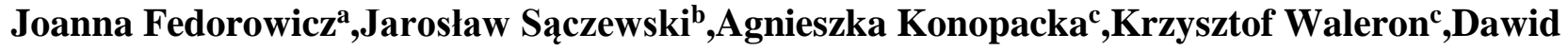 \\ Lejnowski $^{\mathrm{d}}$, Krzesimir Ciura $^{\mathrm{e}}$,Tihomir Tomašič ${ }^{\mathrm{f}}$, Žiga Skok $^{\mathrm{f}}$, Kirsi Savijoki $^{\mathrm{g}}$,Malgorzata \\ Morawska $^{\text {abg }}$, Shella Gilbert-Girardg, Adyary Fallarerog
}

a Department of Chemical Technology of Drugs, Faculty of Pharmacy, Medical University of Gdańsk, Al. Gen. J. Hallera 107, 80-416, Gdańsk, Poland

b Department of Organic Chemistry, Faculty of Pharmacy, Medical University of Gdańsk, Al. Gen. J. Hallera 107, 80-416, Gdańsk, Poland

c Department of Pharmaceutical Microbiology, Faculty of Pharmacy, Medical University of Gdańsk, Al. Gen. J. Hallera 107, 80-416, Gdańsk, Poland

d Department of Biology and Pharmaceutical Botany, Faculty of Pharmacy, Medical University of Gdańsk, Al. Gen. J. Hallera 107, 80-416, Gdańsk, Poland

e Department of Physical Chemistry, Faculty of Pharmacy, Medical University of Gdańsk, Al. Gen. J. Hallera 107, 80-416, Gdańsk, Poland

f Faculty of Pharmacy, University of Ljubljana, Aškerčeva cesta 7, 1000, Ljubljana, Slovenia

g Faculty of Pharmacy, University of Helsinki, Yliopistonkatu 4, 00100, Helsinki, Finland

\section{Keywords}

Antibacterial activity

Drug synthesis

Molecular docking

Enzyme inhibition

Hybrid compounds

Quinolone

\section{Abbreviations}

\begin{tabular}{|c|c|c|c|}
\hline ATCC & American type culture collection & LB & Lysogeny Broth \\
\hline BHI & Brain Heart Infusion & MBC & minimum bactericidal concentration \\
\hline CFU & colonyforming unit & MH & Mueller Hinton \\
\hline CLSI & Clinical and Laboratory Standards & MIC & minimum inhibitory concentration \\
\hline Institute & & ONPG & ortho-nitrophenyl- $\beta$-galactoside \\
\hline DMF & $\mathrm{N}, \mathrm{N}$-dimethylformamide & ParC & topoisomerase IV subunit A \\
\hline DMSO & dimethyl sulfoxide & ParE & topoisomerase IV subunit B \\
\hline GyrA & DNA gyrase A subunit & $\mathrm{PaßN}$ & phenylalanine-arginine $\beta$ - \\
\hline GyrB & DNA gyrase B subunit & & naphthylamide \\
\hline IM & inner membrane & TRIS & tris(hydroxymethyl) aminomethane \\
\hline HEPES & $\begin{array}{l}\text { 4-(2-hydroxyethyl)piperazine-1- } \\
\text { ethanesulfonic acid }\end{array}$ & TSB & Tryptic Soy Broth \\
\hline
\end{tabular}




\section{Highlights}

- Synthesis of quaternary ammonium fluoroquinolones.

- In vitro evaluation against a panel of Gram-positive and negative bacterial strains.

- Efflux, cellular accumulation, resistance, membrane permeabilization, cytotoxicity.

- E. coli DNA gyrase inhibition evaluation.

- DNA gyrase and topoisomerase molecular docking.

\section{Abstract}

A series of novel fluoroquinolone-Safirinium dye hybrids was synthesized by means of tandem Mannich-electrophilic amination reactions from profluorophoric isoxazolones and antibiotics bearing a secondary amino group at position 7 of the quinoline ring. The obtained fluorescent spiro fused conjugates incorporating quaternary nitrogen atoms were characterized by ${ }^{1} \mathbf{H}$ NMR, IR, MS, and elemental analysis. All the synthetic analogues (3a-h and 4a-h) were evaluated for their in vitro antimicrobial, bactericidal, and antibiofilm activities against a panel of Gram positive and Gram-negative pathogenic bacteria. The most active Safirinium $Q$ derivatives of lomefloxacin (4d) and ciprofloxacin (4e) exhibited molar-based antibacterial activities comparable to the unmodified drugs and displayed considerable inhibitory potencies in $E$. coli DNA gyrase supercoiling assays with $\mathrm{IC}_{50}$ values in the low micromolar range. Zwiterionic hybrids were noticeably less lipophilic than the parent quinolones in micellar electrokinetic chromatography (MECK) experiments. The tests performed in the presence of phenylalanine-arginine $\beta$-naphthylamide (PABN) or carbonyl cyanide $m$-chlorophenylhydrazone (CCCP) revealed that the conjugates are to some extent subject to bacterial efflux and cellular accumulation, respectively. Moreover, the hybrids did not exhibit notable cytotoxicity towards the HEK 293 control cell line and demonstrated low propensity for resistance development, as exemplified for compounds $3 \mathrm{~g}$ and $\mathbf{4 b}$. Finally, molecular docking experiments revealed that the synthesized compounds were able to bind in the fluoroquinolonebinding mode at $S$. aureus DNA gyrase and $S$. pneumoniae topoisomerase IV active sites.

\section{Introduction}

Since the disclosure of nalidixic acid by George Lesher in 1962 [1] more than ten thousands congeners have been obtained from which four generations of bactericides with broad spectrum of antibacterial activities have been developed [2]. Quinolone chemotherapeutics target and inhibit the action of homologous type II topoisomerases, DNA gyrase and DNA topoisomerase IV [3]. The quinolone inhibition mechanism has been extensively studied on molecular level. A crystal structure of moxifloxacin in complex with topoisomerase IV demonstrates the quinolone bound by chelation to a noncatalytic magnesium ion and wedged between base pairs at the DNA cleavage site [4]. Fluoroquinolones are amphoteric compounds that exist as zwitterionic, cationic, anionic and neutral species at physiological pH conditions [5]. The neutral forms are more lipophilic than the zwitterionic 
species. The lipophilicity of the fluoroquinolones plays an essential role in their penetration into bacterial cells [6]. It is well-known that introduction of a N-Mannich base functional group can decrease protonation of the parent amine at physiological $\mathrm{pH}$ resulting in an increase of lipophilic properties of a compound and in consequence improvement of its ability to penetrate through biomembranes [7]. It has been established that fluoroquinolones permeate to the cells of Gram-positive bacteria through passive diffusion, however it is assumed that only the neutral species of these compounds can penetrate across the cytoplasmic membranes [8,9]. Conversely, in the case of Gramnegative bacteria, fluoroquinolones are supposed to penetrate the bacterial cells mainly through the hydrophilic way by means of porine channel, and to a lesser extent by the hydrophobic route across the lipid bilayer [10,11]. Consequently, the more hydrophobic a compound is, the better it penetrates through lipid bilayer whilst the adverse is true for the diffusion through hydrophilic porin channels.

Compared to drugs targeting human cells, antibacterial drugs demonstrate higher molecular weights, lower lipophilicity, and larger total polar surface areas. Hence, majority of the antibacterial agents do not comply with Lipinski's "rule of 5", which specify the most favorable drug-like attributes. Antibacterial compounds have always been considered an exemption to these principles indicating a requirement of divergent properties for the penetration into nonhuman cells [12].

Structure-activity relationship (SAR) investigations of fluoroquinolones have proved that the basic group at the C-7 position, the only position that substitution of bulky functional group is permitted, significantly affects their antibacterial spectrum, potency, and safety [13]. Moreover, introduction of increased bulkiness at the C-7 site may contribute to protection against bacterial efflux pumps, and diminish the prospect of antibiotic resistance development of typical bacterial strains [[14], [15], [16]].

Central nervous system (CNS) effects represent one of the most common group of quinolone adverse events, including headache, dizziness, agitation, sleep disorders and in rare instances convulsions. It was suggested that there is a structural analogy between $\gamma$-aminobutyric acid (GABA) and the piperazinyl and pyrrolidinyl side chains present in most quinolones. Unsubstituted piperazines show the greatest binding, however predicting overall CNS liability from GABA inhibition data alone is inefficient, because in-vivo penetration to the brain is also an important variable. As a first approximation, one might assume that quinolones with the highest overall lipophilicity would have the greatest penetration into the CNS and brain. Then the quinolones with the least CNS toxicity would be predicted to be those with bulky $\mathrm{C} 7$ substituents (low GABA binding) and low overall lipophilicity (lower brain penetration). Nevertheless, since relatively few studies determining quinolone lipophilicity $(\log \mathrm{P})$ over a wide range of structures have been published, predicting direct CNS effects for the quinolones is still difficult [17].

Hybridization constitute a convenient method for the development of new drugs with the capability to reduce cross resistance, counterbalance the known side effects associated with the other hybrid part or improve affinity and efficacy compared with the parent drugs. A number of successful approaches to hybrid drugs on the basis of fluoroquinolones have been reported [[18], [19], [20], [21], [22], [23], [24], [25], [26], [27]]. Numerous works have been conducted toward the synthesis of quinolone hybrids that combine diverse types of bioactive molecules including aminoglycosides [28], 
macrolides [29], oxazolidinones [30], isatin [31], benzofuroxan [32] etc. into the C-7 position to obtain drug conjugates, which have shown great potential as novel antimicrobial agents.

Herein, we report the synthesis of hybrid compounds for the purpose of modification of the physicochemical properties of fluoroquinolones and/or synergistic effect through combining piperazinyl quinolones and quaternary ammonium salts (QACs) [33] in one compact structure. The main objective of the project was to design and prepare a series new dual acting hydrophilic antibacterials incorporating a fluoroquinolone drug and a fluorescent triazolinium compound with proved antibacterial properties, aimed at evaluating the hypothesis that a new class of hybrid antibacterial agents can be obtained that exhibit an unique dual antimicrobial mechanism of action: (i) perturbation of the lipid bilayer of the bacterial cytoplasmic membrane and the outer membrane of Gram-negative bacteria due to presence of quaternary ammonium group, and (ii) inhibition of DNA gyrase/bacterial topoisomerase IV elicited by fluoroquinolone portion. Fluorescent properties of these hybrid agents would allow the evaluation of their penetration into the bacterial cell.

\section{RESULTS AND DISCUSSION}

\subsection{Chemistry}

Recently, in our laboratories a new tandem Mannich - electrophilic amination reaction has been discovered, that have led to fluorescent triazolinium salts (Safirinium) [34]. Hence, treatment of isoxazolo[3,4-b]pyridin-3(1H)-one [35] or isoxazolo[3,4-b]quinolin-3(1H)-one [36] with secondary amines in the presence of formaldehyde gave rise to the formation of two series of fluorescent dyes: Safirinium-P (pyridine core) and Safirinium-Q (quinoline core), that feature high quantum yields of fluorescence, very good solubility in water and large Stoke's shifts [34,36]. It is well known that a large number of fluoroquinolone antibacterial drugs feature a secondary aliphatic amino group in their structure, i.e. piperazinyl or piperidinyl groups (Scheme 1). This prompted us to subject a series of (fluoro)quinolones bearing secondary amino group at position 7 to the tandem Mannich electrophilic amination reaction with use of profluorophores 1 and 2, as shown in Scheme 1.

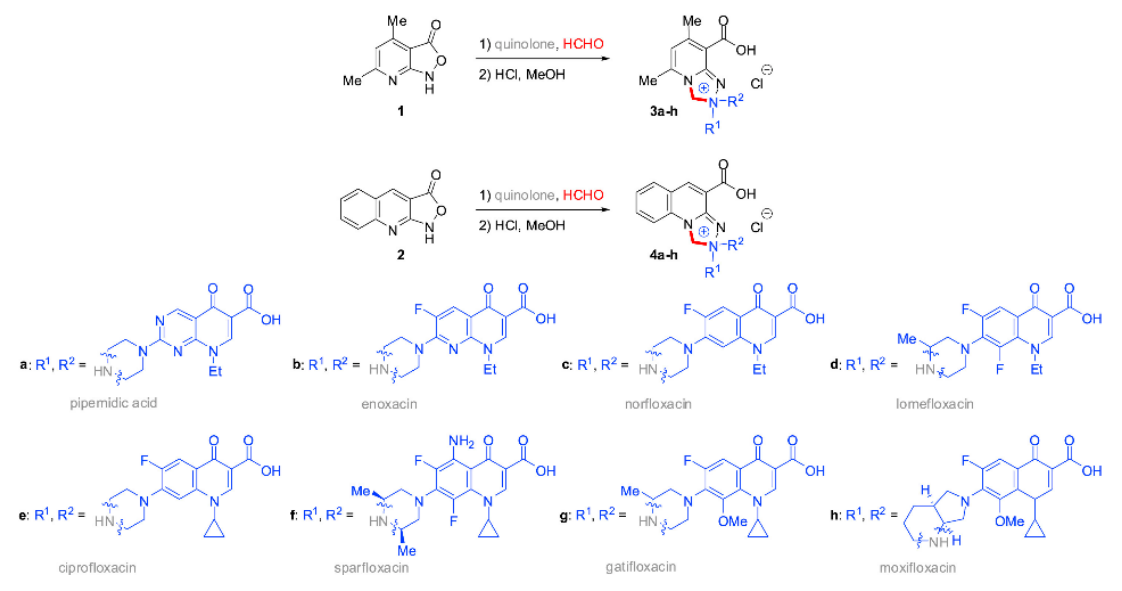

Scheme 1 . Synthesis of hybrid compounds $3 \mathbf{a}-\mathbf{h}$ and $\mathbf{4 a - h}$. 
Quinolone antibiotics subsequently employed to the coupling reactions belong to four fluoroquinolone generations: I - pipemidic acid (a); II - enoxacin (b), norfloxacin (c), lomefloxacin (d), and ciprofloxacin (e); III - sparfloxacin (f); IV - gatifloxacin (g) and moxifloxacin (h). Thus, the reaction of isoxazolones $\mathbf{1}$ and $\mathbf{2}$ with the corresponding fluoroquinolones in the presence of formaldehyde resulted in formation of library of quaternary hybrid compounds linked directly at the basic piperazine or piperazine amine groups. The obtained conjugates in the forms of inner salts were transformed into hydrochlorides upon acidification with $\mathrm{HCl}$ methanol solution aiming to increase the solubility of the products. Cream-colored solid compounds 3a-e,g,h and 4a-f were purified by crystallization, while sparfloxacin derivative $\mathbf{3 f}$ was isolated by means of a preparative HPLC. Safirinium $P$ derivatives 3a-h were obtained in fair yields (20-72\%), while Safirinium $Q$ conjugates 4a-h were afforded in good to excellent yields (73-93\%). Due to the presence of quaternary nitrogen atom in trazolinium ring, an asymmetric center was formed in case of derivatives bearing chiral carbon atoms within cyclic amine ring. Sparfloxacin and moxifloxacin were used for reaction as pure isomers with known absolute configurations and their derivatives $\mathbf{3 f}, \mathbf{h}, \mathbf{4 f}, \mathbf{h}$ were obtained as 1:1 mixtures of two diasereoisomers as evidenced in the NMR experiments. Lomefloxacin and gatifloxacin bearing methyl substituent within the piperazynyl ring were used as a mixture of enantiomers, therefore the coupling reactions resulted in the formation of derivatives $\mathbf{3 d}, \mathbf{g}$ and $\mathbf{4 d}, \mathbf{g}$ in the forms of two diastereomers/enantiomers pairs. The corresponding optical isomers were not isolated and hence they were used in further biological evaluations as mixtures.

\subsection{Lipophilicity}

Lipophilic properties were determined with use of micellar electrokinetic chromatography (MECK). Aqueous micelle solution, above the critical micelle concentration (CMC) filled the capillary in MEKC and formed pseudostationary phase [37]. Briefly, the concept of application of MEKC in order to determine lipophilicity is based on different affinity to the pseudostationary phase [38]. Target compounds interact with micelles and migrate dissolved in the aqueous phase according to their lipophilicity. The more lipophilic the analyte is, the stronger it binds to the micelles and in consequence migrates toward the cathode with lower velocity. The migration data are expressed by the retention factor (log k MECK). Several studies showed correlation between log k MECK and classical $\log$ P values determined by the shake flask method, which proves the effectiveness of MECK in lipophilicity determination [[38], [39], [40], [41]]. The results of the MECK lipophilicity assessments are listed in Table 1. As expected the newly synthesized Safirinium-quinolone hybrids were found to be considerably less lipophilic than the parent fluoroquinolones. Hence, the two nonfluorinated pipemidic acid derivatives $3 \mathrm{~d}$ and $4 \mathrm{a}$ proved the most hydrophilic character within the series. Furthermore, significantly lower log k values were determined for Safirinium P hybrids 3 in comparison to their Safirinium Q counterparts 4. The obtained data also showed that sparfloxacin derivative $4 \mathrm{f}$ incorporating two fluorine atoms, 3,5-dimethylpiperazinyl group and quinoline core was the most lipophilic of the obtained hybrids with the highest log k value of -0.07 . 
Table 1. Log $k$ and $\sigma \log k$ values obtained in MEKC experiments.

\begin{tabular}{lll} 
Compound & log $\mathbf{~}$ & $\boldsymbol{\sigma} \mathbf{l o g} \mathbf{~}$ \\
\hline $\mathrm{a}$ & -0.5725 & 0.0021 \\
4a & -0.4434 & 0.0003 \\
Pipemidic acid & -0.1697 & 0.0044 \\
3b & -0.3984 & 0.0027 \\
4b & -0.2387 & 0.0009 \\
Enoxacin & 0.1564 & 0.0070 \\
3c & -0.2721 & 0.0012 \\
4c & -0.1044 & 0.0057 \\
Norfloxacin & 0.1033 & 0.0049 \\
3d & -0.4791 & 0.0039 \\
4d & -0.2650 & 0.0020 \\
Lomefloxacin & 0.0766 & 0.0003 \\
3e & -0.3214 & 0.0117 \\
4e & -0.1527 & 0.0007 \\
Ciprofloxacin & 0.1039 & 0.0011 \\
3f & -0.2606 & 0.0070 \\
4f & -0.0700 & 0.0041 \\
Sparfloxacin & 0.1161 & 0.0005 \\
3g & -0.4080 & 0.0175 \\
4g & -0.1255 & 0.0036 \\
Gatifloxacin & 0.1010 & 0.0012 \\
3h & $\mathrm{nt}$ & $\mathrm{nt}$ \\
4h & -0.2502 & 0.0036 \\
Moxifloxacin & 0.1083 & 0.0001 \\
\hline
\end{tabular}

\subsection{Antibacterial activity}

The obtained hybrid compounds as well as the unmodified quinolones were tested against a panel of Gram-positive and Gram-negative bacterial strains. Despite higher molecular weight than parent drugs, most of the designed molecules retained the activity against both Gram-positive and Gramnegative microorganisms. MIC and MBC values are summarized in Table 2. In general, Safirinium $Q$ derivatives $\mathbf{4}$ exhibited higher activity than the corresponding Safirinium $P$ analogues $\mathbf{3}$. In most cases MIC values determined for the hybrids expressed in $\mu \mathrm{g} / \mathrm{mL}$ were at least twice higher than these established for the parent drugs. However, despite an approximate doubling the molecular weight relative to the parent quinolones, the molar-based antibacterial activities of the conjugates were comparable to the unmodified drugs. For example, enoxacin derivative $\mathbf{4 b}$ reached minimal inhibitory concentration of $0.25 \mu \mathrm{g} / \mathrm{mL}$ against P. vulgaris along with $1 \mu \mathrm{g} / \mathrm{mL}$ against E. coli and $P$. aeruginosa. Lomefloxacin derivative $\mathbf{4 d}$ was also found to be highly potent against above strains with MIC values of $0.25,0.25$, and $1 \mu \mathrm{g} / \mathrm{mL}$, respectively. This compound exhibited the same activity as free lomefloxacin against $P$. aeruginosa. Moreover, it was effective against $B$. subtilis (MIC of $0.5 \mu \mathrm{g} / \mathrm{mL}$ ). Hybrids $\mathbf{4 d}$ and $\mathbf{4 e}$ exhibited strong activity of $1 \mu \mathrm{g} / \mathrm{mL}$ against $S$. epidermidis clinical isolate. Ciprofloxacin conjugate $4 \mathbf{e}$ showed remarkable activity against E. coli (MIC of $2 \mu \mathrm{g} / \mathrm{mL}$ ) and $P$. vulgaris (MIC of $0.063 \mu \mathrm{g} / \mathrm{mL}$ ) laboratory strains. The later microorganism was found to be the 
most susceptible to the obtained hybrids with MIC values of $0.125 \mu \mathrm{g} / \mathrm{mL}$ for compound 4d, $0.25 \mu \mathrm{g} / \mathrm{mL}$ for $\mathbf{4 b}$ and $\mathbf{3 c}, 0.5 \mu \mathrm{g} / \mathrm{mL}$ for $\mathbf{3 g}, \mathbf{h}$, and $1 \mu \mathrm{g} / \mathrm{mL}$ for $\mathbf{3 b}, \mathbf{d}, \mathbf{f}$. MIC values of the obtained conjugates are no more than fourfold higher than their $\mathrm{MBC}$ values, therefore these fluoroquinolone derivatives can be considered as bactericidal agents. 
Table 2. MIC and MBC values determined for compounds 3a-h and 4a-h as well as their parent compounds.

\begin{tabular}{|c|c|c|c|c|c|c|c|c|c|c|c|c|}
\hline \multirow[b]{3}{*}{ Compound } & \multicolumn{12}{|c|}{ MIC/MBC $[\mu \mathrm{g} / \mathrm{mL}]$} \\
\hline & \multicolumn{8}{|c|}{ Laboratory strains } & & \multicolumn{3}{|c|}{ Clinical strains } \\
\hline & $\begin{array}{l}\text { S. aureus } \\
\text { ATCC } \\
6538\end{array}$ & $\begin{array}{l}\text { S. aureus } \\
\text { MRSA } \\
\text { N315 }\end{array}$ & $\begin{array}{l}\text { S.epidermidis } \\
\text { ATCC } 14990\end{array}$ & $\begin{array}{l}\text { E. hirae } \\
\text { ATCC } \\
1052\end{array}$ & $\begin{array}{l}\text { B. subtilis } \\
\text { ATCC } \\
6633\end{array}$ & $\begin{array}{l}\text { E. coli } \\
\text { ATCC } \\
8739\end{array}$ & $\begin{array}{l}\text { P. aeruginosa } \\
\text { ATCC } \\
9027\end{array}$ & $\begin{array}{l}\text { P. vulgaris } \\
\text { NCTC } \\
4635\end{array}$ & $\begin{array}{l}\text { S. aureus } \\
\text { MRSA } \\
6347\end{array}$ & $\begin{array}{l}\text { S. epidermidis } \\
\text { MRSE13199 }\end{array}$ & S.pneumoniae & $\begin{array}{l}\text { S.marcescens } \\
12795\end{array}$ \\
\hline $3 \mathbf{a}$ & $>512$ & $>512$ & $>512$ & $>512$ & $>512$ & $>512$ & $>512$ & $256 />512$ & $>512$ & $>512$ & $>512$ & $>512$ \\
\hline $4 a$ & $512 / 512$ & $512 / 512$ & $256 / 256$ & $>512$ & $64 / 64$ & $16 / 16$ & $128 / 128$ & $16 / 16$ & $256 / 256$ & $8 / 16$ & $>512$ & $128 / 128$ \\
\hline $\begin{array}{l}\text { Pipemidic } \\
\text { acid }\end{array}$ & $64 / 128$ & $32 / 32$ & $32 / 32$ & $>512$ & $2 / 2$ & $2 / 2$ & $8 / 8$ & $0.004 / 0.004$ & $32 / 32$ & $32 / 64$ & $>512$ & $2 / 2$ \\
\hline $3 \mathbf{b}$ & $128 / 128$ & $128 / 128$ & $128 / 128$ & $16 / 32$ & $16 / 16$ & $8 / 16$ & $512 / 512$ & $1 / 2$ & $128 / 128$ & $64 / 128$ & $>512$ & $64 / 128$ \\
\hline $4 b$ & $8 / 8$ & $8 / 8$ & $4 / 4$ & $512 / 512$ & $2 / 2$ & $1 / 2$ & $1 / 1$ & $0.25 / 0.5$ & $4 / 16$ & $2 / 2$ & $256 / 512$ & $8 / 16$ \\
\hline Enoxacin & $1 / 1$ & $1 / 1$ & $0.5 / 2$ & $64 / 64$ & $0.125 / 0.125$ & $0.25 / 0.5$ & $0.5 / 0.5$ & $0.032 / 0.063$ & $0.5 / 1$ & $0.25 / 0.25$ & $32 />512$ & $0.25 / 0.25$ \\
\hline $3 c$ & $64 / 128$ & $128 / 128$ & $64 / 128$ & $>512$ & $16 / 64$ & $4 / 8$ & $256 />512$ & $0.25 / 0.5$ & $64 / 128$ & $32 / 32$ & $>512$ & $64 / 128$ \\
\hline $4 c$ & $64 / 64$ & $64 / 64$ & $32 / 32$ & $>512$ & $16 / 16$ & $4 / 4$ & $64 / 64$ & $2 / 2$ & $32 / 32$ & $64 / 64$ & $>512$ & $32 / 32$ \\
\hline Norfloxacin & $0.25 / 0.25$ & $1 / 2$ & $0.5 / 2$ & $64 / 64$ & $0.125 / 0.125$ & $0.032 / 0.063$ & $0.25 / 0.25$ & $0.016 / 0.016$ & $1 / 1$ & $0.125 / 0.125$ & $128 />512$ & $0.25 / 0.25$ \\
\hline 3d & $64 / 64$ & $128 / 128$ & $32 / 64$ & $>512$ & $8 / 8$ & $4 / 8$ & $128 />512$ & $1 / 1$ & $128 / 128$ & $16 / 32$ & $>512$ & $64 / 64$ \\
\hline $4 d$ & $2 / 2$ & $2 / 2$ & $4 / 4$ & $512 / 512$ & $0.5 / 0.5$ & $0.25 / 0.5$ & $1 / 1$ & $0.125 / 0.125$ & $4 / 16$ & $1 / 2$ & $512 / 512$ & $2 / 2$ \\
\hline Lomefloxacin & $1 / 1$ & $0.5 / 1$ & $1 / 2$ & $128 / 128$ & $0.125 / 0.125$ & $0.063 / 0.125$ & $1 / 1$ & $0.008 / 0.008$ & $0.5 / 1$ & $0.25 / 0.25$ & $16 />512$ & $0.5 / 0.5$ \\
\hline $3 e$ & $128 / 128$ & $32 / 32$ & $64 / 64$ & $>512$ & $8 / 8$ & $8 / 8$ & $128 / 128$ & $2 / 2$ & $128 / 128$ & $4 / 8$ & $>512$ & $64 / 64$ \\
\hline $4 e$ & $4 / 4$ & $4 / 4$ & $2 / 2$ & $>512$ & $1 / 2$ & $2 / 2$ & $2 / 2$ & $0.063 / 0.063$ & $2 / 2$ & $1 / 1$ & $256 / 512$ & $1 / 2$ \\
\hline Ciprofloxacin & $0.25 / 0.5$ & $1 / 1$ & $0.25 / 0.25$ & $128 / 128$ & $0.032 / 0.063$ & $0.032 / 0.032$ & $0.5 / 0.5$ & $0.008 / 0.008$ & $0.25 / 0.5$ & $0.125 / 0.125$ & $8 />512$ & $0.125 / 0.125$ \\
\hline $3 f$ & $8 / 16$ & $8 / 8$ & $4 / 16$ & $>512$ & $2 / 2$ & $4 / 4$ & $32 />512$ & $1 / 2$ & $4 / 8$ & $2 / 4$ & $>512$ & $32 / 32$ \\
\hline 4f & $8 / 8$ & $32 / 128$ & $8 / 8$ & $>512$ & $4 / 4$ & $4 / 4$ & $64 / 64$ & $2 / 2$ & $32 / 32$ & $16 / 32$ & $>512$ & $64 / 64$ \\
\hline Sparfloxacin & $0.125 / 0.25$ & $0.125 / 0.125$ & $0.125 / 0.125$ & $32 / 32$ & $0.063 / 0.063$ & $0.016 / 0.032$ & $0.125 / 0.125$ & $0.004 / 0.008$ & $0.063 / 0.063$ & $0.032 / 0.032$ & $0.25 / 128$ & $0.5 / 1$ \\
\hline $3 g$ & $8 / 16$ & $8 / 8$ & $8 / 16$ & $>512$ & $2 / 2$ & $2 / 2$ & $32 / 256$ & $0.5 / 0.5$ & $8 / 16$ & $4 / 8$ & $128 / 256$ & $32 / 32$ \\
\hline $4 \mathrm{~g}$ & $16 / 16$ & $32 / 32$ & $32 / 32$ & $>512$ & $32 / 32$ & $0.25 / 0.5$ & $128 / 128$ & $4 / 4$ & $16 / 16$ & $4 / 8$ & $128 / 256$ & $64 / 64$ \\
\hline Gatifloxacin & $0.25 / 0.25$ & $0.125 / 0.125$ & $0.125 / 0.25$ & $8 / 16$ & $0.032 / 0.063$ & $0.016 / 0.032$ & $0.25 / 0.25$ & $0.008 / 0.008$ & $0.125 / 0.125$ & $0.063 / 0.063$ & $1 / 256$ & $0.25 / 0.5$ \\
\hline $3 \mathbf{h}$ & $4 / 8$ & $4 / 4$ & $4 / 4$ & $512 / 512$ & $0.5 / 0.5$ & $4 / 8$ & $64 / 128$ & $0.5 / 0.5$ & $8 / 8$ & $1 / 4$ & $32 / 256$ & $32 / 32$ \\
\hline $4 h$ & $8 / 8$ & $8 / 8$ & $2 / 8$ & $>512$ & $2 / 2$ & $8 / 16$ & $128 / 128$ & $0.5 / 2$ & $4 / 4$ & $2 / 2$ & $64 / 64$ & $32 / 64$ \\
\hline Moxifloxacin & $0.125 / 0.125$ & $0.125 / 0.25$ & $0.063 / 0.125$ & $16 / 32$ & $0.032 / 0.032$ & $0.125 / 0.25$ & $16 / 16$ & $0.004 / 0.008$ & $0.063 / 0.063$ & $0.032 / 0.032$ & $16 / 64$ & $0.25 / 0.5$ \\
\hline
\end{tabular}


It should be emphasized that more hydrophilic Safirinium $P$ hybrids 3 ( $\log k$ from -0.5725 to -0.2606 ) were much less active against the tested microorganisms than the corresponding less hydrophilic conjugates of Safirinium $Q 4$ (log $k$ from -0.4434 to -0.07$)$. These results may indicate strong correlation between antibacterial activity and lipophilic properties of the tested antibacterial agents. This observation stays in agreement with a general principle that antibacterial and antiproliferative activities of fluoroquinolones strongly depends on lipophilic profile, which condition their diffusion into bacterial $[42,43]$ and human cancer cells $[44,45]$. In this context, increase in the overall lipophilic character of a quinolone derivative usually involves introduction of a bulky group at the N-4 position of piperazine, or more generally, at the C-7 position of the parent drug [42]. As Safirinium $Q$ conjugates 4 , incorporating large triazoloquinolinium moiety at the N-4 position of piperazine, are significantly less lipophilic than the free quinolones, and yet they retain antibacterial activity, the direct proportion between lipophilicity/C-7 bulkiness and biological potencies of these compounds may be questionable. This could be especially true for quinolones penetrating into nonhuman cells since, as mentioned earlier, most of the antibacterial agents demonstrate different properties than the drugs targeting human cells [12].

Microscopic images of $E$. coli cells treated with compound $4 \mathbf{e}$ and untreated cells used as a negative control are presented in Fig. 1. The cells incubated without the tested compound are regular-shaped and form short agglomerates (maximum 2-3 cells). However, the sample treated with conjugate 4e reveals significant reduction in cell number and morphological disorders. The bacterial cells are swelled and they do not separate after division forming long cords. Occurrence of cell aggregates may indicate disruption in cell division cycle.
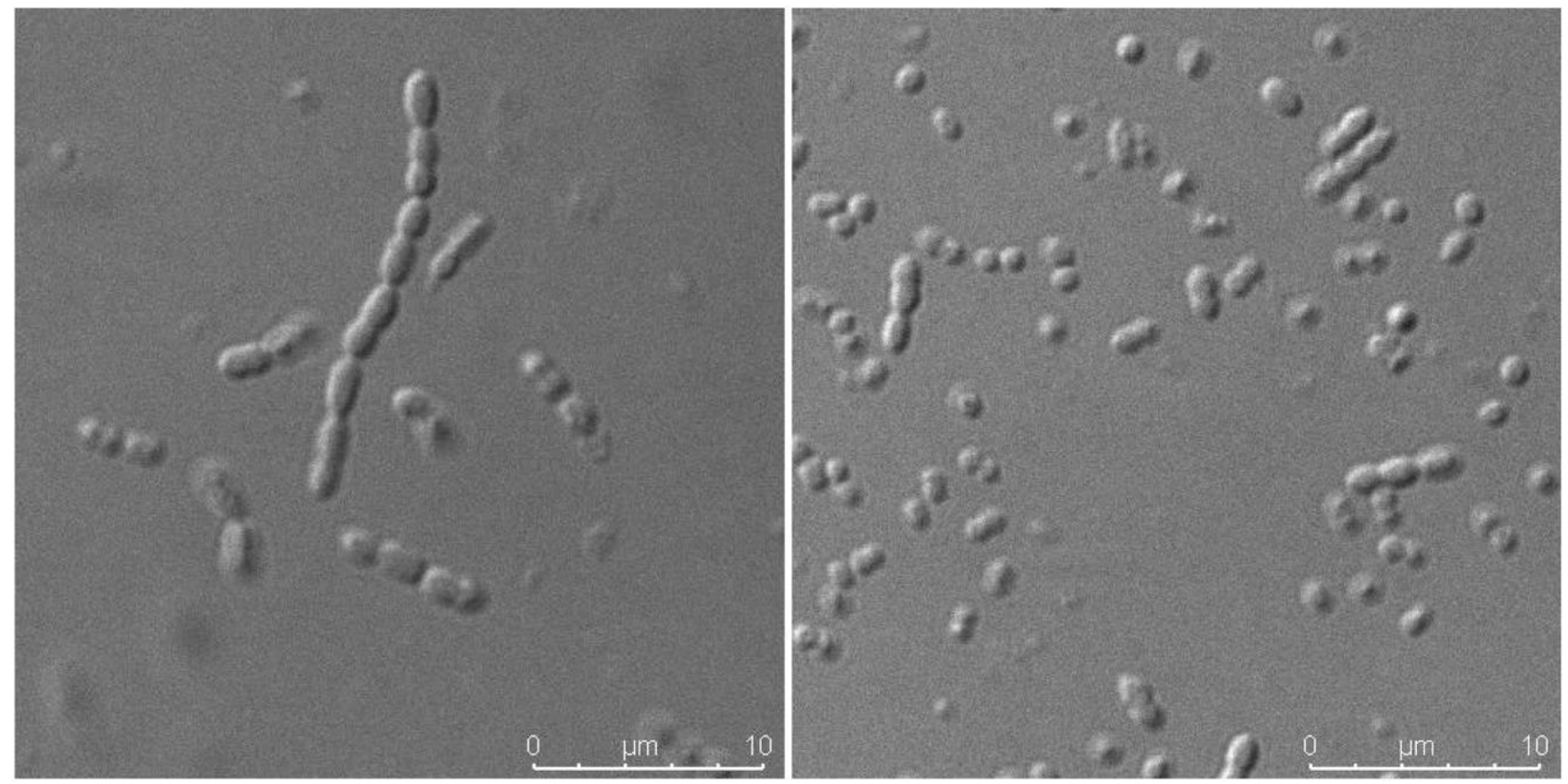

Figure 1. E. coli cells treated with compound 4e (left) and untreated (right), White Light Laser Confocal Microscope Leica TCA SP8 X (TCS - True Confocal System). 


\subsection{Examination of the modes of action}

The most promising compounds were selected for further evaluations by means of determination of their inhibitory activity against E. coli DNA gyrase supercoiling assay. Inhibitory ability was measured using commercial assay kit (Inspiralis Ltd, England). The results obtained are presented in Table 3 as residual activities (RA) of the enzyme at 10 and $1 \mu \mathrm{M}$ of the tested compound, or as $\mathrm{IC}_{50}$ values for the more active compounds (RA $<35 \%$ at $10 \mu \mathrm{M})$.

\section{Table 3. Residual activities (RA) and IC50 values determined for compounds 4b,d-f,h and ciprofloxacin against $E$. coli DNA gyrase.}

\begin{tabular}{|l|l|l|l|}
\hline Compound & $\mathbf{R A}$ in $\mathbf{1 0} \boldsymbol{\mu M}[\mathbf{\%}]$ & $\mathbf{R A}$ in $\mathbf{1} \boldsymbol{\mu M}[\mathbf{\%}]$ & $\mathbf{I} \mathbf{C}_{\mathbf{5 0}}[\boldsymbol{\mu M}]$ \\
\hline $\mathbf{4 b}$ & 73 & 100 & - \\
\hline $\mathbf{4 d}$ & 11 & 97 & 2.44 \\
\hline $\mathbf{4 e}$ & 34 & 97 & 6.02 \\
\hline $\mathbf{4 f}$ & 35 & 73 & - \\
\hline $\mathbf{4 h}$ & 42 & 92 & - \\
\hline Ciprofloxacin & - & 7 & 0.122 \\
\hline
\end{tabular}

Primary screening revealed that the tested compounds are potent DNA gyrase inhibitors. Compounds 4d and 4e displayed considerable potencies with $\mathrm{IC}_{50}$ values in the low micromolar range, however their activity was weaker than that of bare ciprofloxacin. Moderate inhibitory activity against DNA gyrase combined with preserved in vitro antibacterial activity, as determined for the hybrid quaternary fluoroquinolones, may suggest that the studied compounds engage a complex mode of action.

In order to investigate additional mode of action comprising bacterial membrane permeation characteristic for quaternary ammonium salts [46], permeabilization experiments were conducted. The ability of the obtained compounds to permeate E. coli ATCC 8739 inner membrane (IM) was evaluated as function of cytoplasmic $\beta$-galactosidase release, with bacteria grown in lactose containing medium, and determined optically at $415 \mathrm{~nm}$. Assays were performed with $10^{9} \mathrm{CFU} / \mathrm{ml}$ in $10 \mathrm{mM}$ Na-phosphate buffer, $\mathrm{pH} 7.5$, containing $100 \mathrm{mM} \mathrm{NaCl}$ and $1.5 \mathrm{mM} \mathrm{ONPG}$. In a preliminary test, we analysed permeation of the IM in a dose-dependent manner at $0.5-512 \mu \mathrm{g} / \mathrm{mL}$ (data not shown). Progressive release of the cytoplasmic $\beta$-galactosidase was observed when cells were treated with concentrations above bactericidal. Compound $4 \mathbf{e}$ at concentration $128 \mu \mathrm{g} / \mathrm{mL}$ caused considerable release of the enzyme into the medium within 90 min of incubation with cells after a lag time of about $10 \mathrm{~min}$ (Fig. S3, Supplemental Information). However, free ciprofloxacin in the same concentration also displayed permeabilization activity, nevertheless the effect was delayed and observed to a lesser extent. 


\subsection{Antibiofilm activity}

Biofilms are surface-attached microbial community structures responsible for several chronic diseases that are difficult to treat. They represent predominant form of growth in vivo and can be formed by various microbial species from free-floating planktonic cells in response to several different factors including availability of nutrients and cellular recognition of attachment sites [47]. Bacterial biofilms are important from a clinical perspective since they cause numerous infections in humans, such us urinary tract infections, formation of dental plaque or infections in cystic fibrosis [48]. Moreover, these bacterial growth forms are often formed on the inert surfaces of implants such as prostheses, stents, cardiac valves, vascular grafts, urinary catheters, and intrauterine devices [49]. These heterogeneous and dynamic bacterial aggregates exhibit the ability to resist phagocytosis as well as the body's defence system due to mechanical strength and stability so that they are able to withstand the shear forces [50]. The presence of quaternary ammonium nitrogen atom possessing stable positive charge may facilitate efficient penetration of the complex extracellular matrix and uptake of drug molecules [51,52]. Considering these facts, the novel hybrid compounds that specifically target and inhibit the biofilm formation would constitute a valuable alternative to the traditional antibiotics. Compounds $\mathbf{4 b}, \mathbf{d}$, and e exhibiting good antibacterial activity were screened for their antibiofilm activity against biofilm-forming pathogens causing opportunistic respiratory, skin, and bone infections, P. aeruginosa ATCC 9027 and S. aureus 6538. Biofilm formation inhibition as well as mature biofilm degradation experiments were undertaken by means of total biomass crystal violet staning [53]. The results are shown in Fig. 2. All the tested compounds were

P. aeruginosa - biofilm inhibition

S. aureus - biofilm inhibition
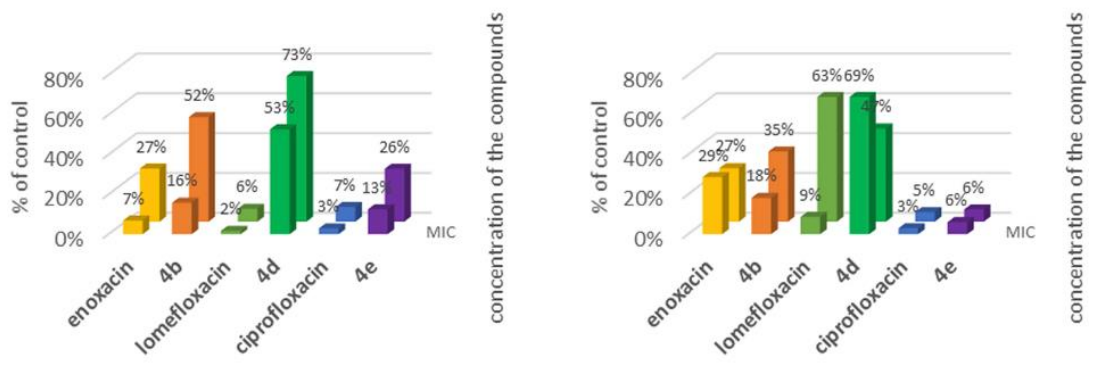

P. aeruginosa - biofilm degradation

S. aureus - biofilm degradation
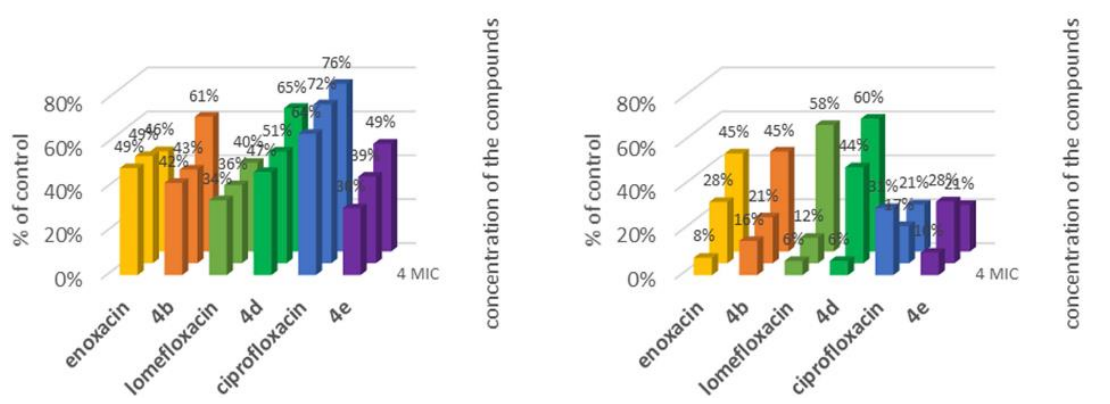

Figure 2. The effects of fluoroquinolones against bacterial biofilms $P$. aeruginosa (left panel) and S. aureus (right panel): (top panel) prior to biofilm formation (pre-exposure) and (bottom panel) post-biofilm formation (post-exposure). The standard deviations do not exceed $20 \%$. 
able to reduce the biofilm formation at the concentration of 1x MIC and 0.5x MIC towards both strains tested (pre-exposure). Compound $\mathbf{4 e}$ exhibited significant activity comparable to ciprofloxacin, especially towards $S$. aureus biofilm. Nevertheless, the novel conjugates displayed slightly weaker biofilm inhibition activity than the parent fluoroquinolones. Furthermore, derivative 4e was found to be highly potent against $P$. aeruginosa in the mature biofilm degradation tests (postexposure). This compound showed notably higher activity than free ciprofloxacin. All the tested conjugates displayed anti-biofilm activities towards $S$. aureus, comparable to these assessed for the parent drugs.

The results presented above have been validated by another research laboratory (Finland). Parallel pre-exposure and post-exposure S. aureus ATCC 25923 biofilm experiments with use of resazurin and crystal violet staining were performed. Rsaurin was used to measure biofilm viability, while crystal violet staining allowed total biomass measurments.

Hybrids $\mathbf{4 b}, \mathbf{d}, \mathbf{e}$ were able to inhibit nearly $100 \%$ of biofilm viability within the concentration range of $2.5-20 \mu \mathrm{M}$ when exposed to single-cell bacteria prior to the initiation of the biofilm formation process (Fig. S4). Total biomass of the formed biofilms was significantly decreased by the tested compounds at concentrations above $2.5 \mu \mathrm{M}$. However, very low concentrations (below $0.625 \mu \mathrm{M}$ ) of compounds $\mathbf{4 b}$ and $\mathbf{4 d}$ induced biofilm formation (Fig. S4). The conjugate $\mathbf{4 e}$ was found to be the most potent in post-exposure experiments inhibiting almost $100 \%$ of biofilm viability and nearly $50 \%$ of total biomass at the concentration of $40 \mu \mathrm{M}$ (Fig. S5). Antibiofilm activity of this compound was similar or higher than its parent drug ciprofloxacin (Fig. S5). These results indicate that compound $\mathbf{4 e}$ is able to penetrate extracellular matrix in mature biofilms more efficiently than the conventional antibiotic.

\subsection{Resistance development}

A number of various mechanisms can be involved in bacterial resistance development, eg. modifications of the antimicrobial molecule, prevention to reach the antibiotic target (such as decreasing penetration or actively extruding the antimicrobial compound), changes and/or bypass of target sites, and resistance due to global cell adaptive processes [54]. A common approach to evade fast developing bacterial resistance caused by spontaneous mutations in bacterial genome involves the use of hybrid drugs.

The most active compounds were further selected to investigate the developing rate of bacterial resistance. The tested bacterial strains were exposed to sublethal concentrations of the analysed compounds for sustained passages. MIC values were recorded after 5, 10 and 15 passages (Fig. 3). The majority of conjugates displayed reduced likelihood of resistance development in comparison to the parent drugs. MICs increased slowly (only 1 or 2 dilution steps) upon 15 passages. Contrarily, faster development of resistance to parent quinolones was observed, as evidenced by rapid increase of MICs in the range of 2-5 dilution steps. 

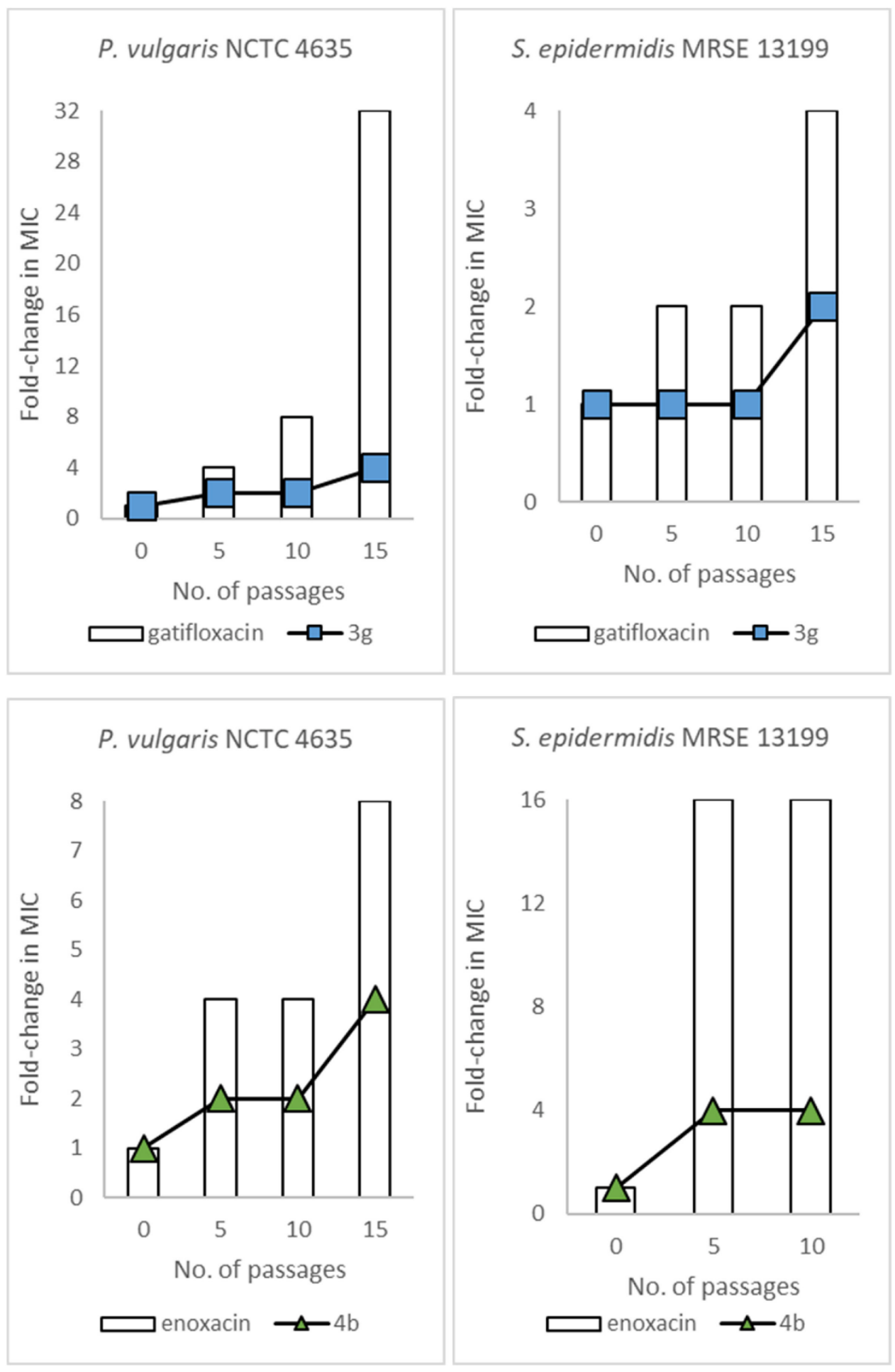

Figure 3. Test of development of resistance to compounds $\mathbf{3 g}$ and $\mathbf{4 b}$ as well as their parent drugs by serial passages in liquid medium, MIC were recorded at the end of 5, 10 and 15 passage.

For example, after 15 passages, $P$. vulgaris had developed a 4-fold increase in MIC for compound $\mathbf{3 g}$ (2 versus $0.5 \mu \mathrm{g} / \mathrm{mL}$ ), while the relative MIC value of its parent drug, gatifloxacin, increased 32-fold (5 dilution steps). Development of $S$. epidermidis resistance to compound $\mathbf{3 g}$ was strongly delayed (approximately 2 times when compared to the parent drug). Also, enoxacin derivative $\mathbf{4 b}$ was found to be less susceptible to resistance development than its parent drug. MIC of enoxacin determined 
after 10 passages of S. epidermidis increased 16-fold (4 dilution steps), while only 4-fold for compound $\mathbf{4 b}$ ( 2 dilution steps). The latter compound induced $P$. vulgaris resistance at a slower rate than the parent drug.

\subsection{Efflux evaluation}

The complete sequencing of bacterial genomes has revealed that E. coli contains 37 genes efflux pump transporters from five families: MFS (major facilitator superfamily), SMR (small multidrug resistance), RND (resistance nodulation cell division), ABC (ATP-binding cassette), and MATE (multidrug and toxic compound extrusion) [55]. AcrAB-TolC system, which belongs to RND family, is considered to be predominant efflux transporter in E. coli involved in multidrug resistance [56].

To evaluate susceptibility of $E$. coli efflux pump system to the obtained conjugates, compounds $\mathbf{4 c -}$ $\mathbf{e}, \mathbf{g}$ and $\mathbf{4 c - e}, \mathbf{g}$ were additionally tested against $E$. coli ATCC 8739 in the presence of phenylalaninearginine $\beta$-naphthylamide (PA $\beta \mathrm{N}$ ) at the concentration of $50 \mu \mathrm{g} / \mathrm{mL}$ (Table 4). PA $\beta \mathrm{N}$ is a preferential substrate for efflux pumps and it is routinely used in combination with antibiotics to assess their efflux vulnerability. The presence of PA $\beta \mathrm{N}$ increased the activity of ciprofloxacin derivatives $3 \mathbf{e}$ and $4 \mathbf{e}$ against E. coli 8-fold $(\mathrm{MIC}=0.5 \mu \mathrm{g} / \mathrm{mL})$ and 16-fold $(\mathrm{MIC}=0.25 \mu \mathrm{g} / \mathrm{mL})$, respectively, which suggests that these compounds are liable to bacterial efflux. For compounds $\mathbf{3 c}, \mathbf{d}, \mathbf{g}$ and $\mathbf{4 c}, \mathbf{d}, \mathbf{g}, 2$-fold stronger inhibition was observed in the presence of PA $\beta N$. These results also indicate that the aforementioned compounds are to some extent susceptible to bacterial efflux.

Table 4. MIC and MBC values determined for compounds 3a-h and 4a-h against E. coli ATCC 8739 in the presence of PAßN at concentration of $50 \mu \mathrm{g} / \mathrm{mL}$.

\begin{tabular}{|l|l|l|}
\hline Compound & MIC/MBC $[\boldsymbol{\mu g} / \mathbf{m L}]$ & Activity increase \\
\hline $\mathbf{3 b}$ & $4 / 16$ & 2-fold \\
\hline $\mathbf{4 b}$ & $0.5 / 1$ & 2-fold \\
\hline $\mathbf{3 d}$ & $2 / 4$ & 2-fold \\
\hline $\mathbf{4 d}$ & $0.125 / 0.25$ & 2-fold \\
\hline $\mathbf{3 e}$ & $0.5 / 2$ & 16-fold \\
\hline $\mathbf{4 e}$ & $0.25 / 0.5$ & 8-fold \\
\hline $\mathbf{3 g}$ & $1 / 2$ & 2-fold \\
\hline $\mathbf{4 g}$ & $0.125 / 0.5$ & 2-fold \\
\hline
\end{tabular}

Conjugates 3a-h and 4a-h display strong fluorescence due to the presence of Safirinium core (Supplemental Information, Table S1, Fig. S1). Compound 4e allowed for visualisation of E. coli cells by means of confocal microscopy (Supplemental Information, Fig. S2). No specific affinity for cell structures or accumulation in membranes were observed (data not shown). Fluorescence assay was used to further investigate the effects of efflux pump system [57]. Carbonyl cyanide $m$ chlorophenylhydrazone (CCCP) has been used to study cellular accumulation in Gram-negative bacteria for a wide range of compounds [[58], [59], [60]] due to its ability to collapse the proton 
motive force [61], which is the source of energy utilized by MFS, SMR, and RND pumps [55]. Cellular accumulation of the tested compound was measured in the presence or absence of CCCP. The fluorescence intensity of E. coli pretreated with $100 \mu \mathrm{M}$ of CCCP $\left(10 \mathrm{~min}, 37^{\circ} \mathrm{C}\right)$ before incubation with 4e significantly increased compared to the untreated cells (Fig. 4). This result confirms that accumulation of the conjugate increases when efflux pumps are inhibited. Linear growth of fluorescence indicates dose-dependent cellular accumulation of $\mathbf{4 e}$.

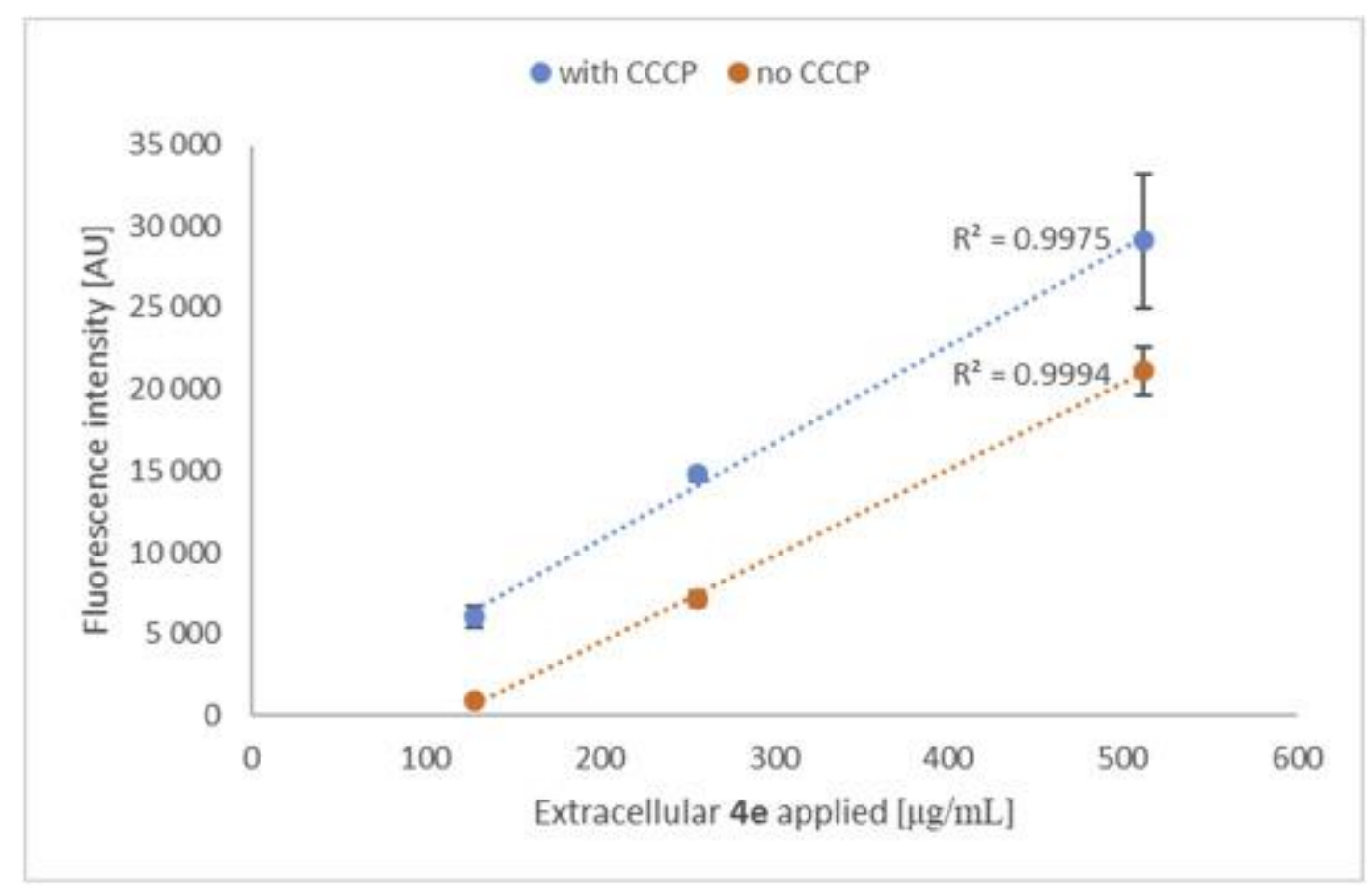

Figure 4. Fluorescence measurements of $4 \mathbf{e}$ cellular accumulation in E. coli ATCC 8739 assessed in the presence or absence of CCCP.

\subsection{Cytotoxicity evaluation}

The cytotoxicity of the prepared compounds $\mathbf{3 a - h}$ and $\mathbf{4 a - h}$ was examined in human embryonic kidney 293 cells (HEK 293) using the 3-(4,5-dimethylthiazol-2-yl)-2,5-diphenyltetrazolium bromide (MTT) cell viability assay [62,63]. No reducing trends to the cell viability or changes in cell morphology were observed (data not shown). All the tested compounds were found to be non-toxic up to the concentration of $20 \mu \mathrm{M}$, which proves their potential for development of novel antibacterial agents.

\subsection{Molecular docking}

Docking studies were undertaken to rationalize the observed antibacterial activity and investigate the interactions of the newly prepared hybrids in the DNA gyrase catalytic site. Molecular modeling was performed using crystal structures of enzyme-DNA complexes obtained from the Protein Data Bank: DNA gyrase and topoisomerase IV from $S$. aureus and $S$. pneumoniae, respectively (PDB codes: $5 \mathrm{cdq}$ [64] and 3rae [65]). The obtained hybrids in deprotonated forms, as well as their parent drugs in 
zwitterionic forms, were docked with use of OpenEye software [66]. All novel conjugates were able to bind in the fluoroquinolone-binding mode at both active sites of enzymes with docking scores comparable to the parent drugs. In almost all cases the carboxylate oxygen atoms of the quinolone core formed hydrogen bonds with serine side chain (Ser84 in S. aureus GyrA and Ser79 in S. pneumoniae ParC). Magnesium ion coordinated in the active centre of the enzyme was chelated with quinolone carboxylate and carbonyl oxygen atoms. The wedge-shaped quinolone core was stacked between base pairs at the DNA cleavage site and formed $\pi$ - $\pi$ interactions. Safirinium part of the conjugate adhered tightly in the binding pocket forming several van der Waals interactions. In general, for most compounds, quaternary nitrogen atom within triazolinium ring interacted via attractive charge with a glutamic acid residue of GyrB/ParE. For some compounds, additional hydrogen bonds were formed between the carboxylate group of the Safirinium part of the hybrid and basic side chains of amino acids, $\mathrm{NH}$ groups in protein backbone, or nucleobases.

Compounds $4 \mathbf{d}, \mathbf{e}$ and $\mathbf{3 h}$ were the most active conjugates within the series against $S$. aureus laboratory strains, both ATCC 6538 and MRSA N315, showing MIC values of $2 \mu \mathrm{g} / \mathrm{mL}$ for 4d and $4 \mu \mathrm{g} / \mathrm{mL}$ for $\mathbf{4 e}$ and $\mathbf{3 h}$. Moreover, these conjugates were highly active against $S$. aureus MRSA 6347 clinical isolate with MIC values of 4,2 , and $8 \mu \mathrm{g} / \mathrm{mL}$, respectively. The antibacterial activity of these compounds was confirmed by docking results with $S$. aureus DNA gyrase - the compounds were ranked higher than their parent drugs. Hybrid $\mathbf{3 h}$ reached the best binding scoring function rank among other conjugates with S. pneumoniae topoisomerase IV, which was consistent with MIC results: moxifloxacin derivative $\mathbf{3 h}$ was the most active conjugate from the obtained compounds against S. pneumoniae clinical isolate and exhibited MIC value of $32 \mu \mathrm{g} / \mathrm{mL}$. However, the binding score as well as the biological activity (MIC value of $16 \mu \mathrm{g} / \mathrm{mL}$ ) were slightly inferior compared to the parent drug, ie. bare moxifloxacin.

Molecular structures of the highest scored poses of compound $\mathbf{3 h}$ docked in the active sites of analysed enzymes are presented in Figure 5. Hydrogen bond lengths between quinolone carboxylate and serine hydroxyl groups are in the range of 2.3-3.2 A, which is in agreement with corresponding lengths of original drugs found in crystal structures (2.8-3.1 A). Several hydrophobic and $\pi-\pi$ as well as halogen (fluorine C6) interactions are formed between quinolone and DNA base rings in both active sites of enzymes. Positively charged nitrogen atom present in triazolinium ring is stabilized with Glu477 of S. aureus GyrB or Glu474 of S. pneumoniae ParE. Glu474 of S. pneumoniae ParE forms anion- $\pi$ interactions with pyridine ring while Arg458 of $S$. aureus GyrB binds through a hydrogen bond with a carboxylate group of the pyridine ring.

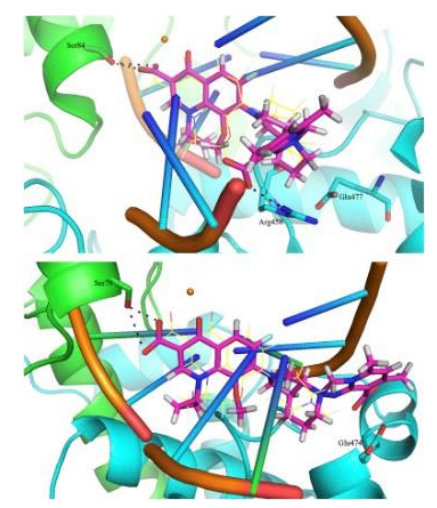

Figure 5. The highest scored poses of $\mathbf{3 h}$ (in magenta sticks) docked in the cleavage site of $S$. aureus DNA gyrase (up) and S. pneumoniae topoisomerase IV (down) active sites. Magnesium ion as orange sphere; subunits GyrA/ParC and GyrB/ParE in green and blue, respectively; original ligands form crystal structures, moxifloxacin and levofloxacin, respectively, in yellow sticks. For clarity, only relevant amino acids are presented. Hydrogen bonds are indicated as dotted lines. The Figure was prepared by PyMOL 1.5.0.3. (For interpretation of the references to color in this figure legend, the reader is referred to the Web version of this article.) 


\section{Conclusions}

In summary, two series of novel (fluoro)quinolone-Safirinium $P / Q$ dye hybrids were designed, synthesized and evaluated for their antibacterial activity. Unlike other zwitterionic quinolones, the obtained conjugates incorporate a permanent positive charge within the triazolinium ring and hence they lack typical $\mathrm{pH}$ dependent uncharged/deprotonated equilibrium that would condition their lipophilicity and facilitate passive diffusion through the lipid bilayer into the bacterial cells. The micellar electrokinetic chromatography experiments proved that the zwitterionic hybrids are significantly more hydrophilic than the parent quinolones. Yet at the same time, they retain antimicrobial, bactericidal, and antibiofilm activities against Gram positive and Gram-negative pathogenic bacteria. In particular, lomefloxacin (4d) and ciproflixacin (4e) Safirinium $Q$ conjugates exhibited good potencies in inhibiting the growth of Staphylococcus aureus ATCC 6538, Staphylococcus aureus MRSA N315, Staphylococcus epidermidis ATCC 14990, Bacillus subtilis ATCC 6633, Escherichia coli ATCC 8739, Pseudomonas aeruginosa ATCC 9027, Proteus vulgaris NCTC 4635 Staphylococcus aureus MRSA 6347, Staphylococcus epidermidis MRSE 13199, and Serratia marcescens 12795 . The results of in vitro enzymatic activity measurements using the E. coli DNA supercoiling assay showed that most active compounds $\mathbf{4 d}$ and $\mathbf{4 e}$ inhibit $E$. coli DNA gyrase in low micromolar range ( $\mathrm{IC}_{50}$ values of 2.44 and $6.02 \mu \mathrm{M}$, respectively). Molecular docking studies indicate that the obtained compounds are able to interact with type II topoisomerases in fluoroquinolone-binding mode. Further experiments revealed that the hybrids do not display cytotoxicity towards human cells and to some extent they are susceptible to the efflux mechanism in Gram-negative bacteria. Furthermore, hybrid $\mathbf{4 b}$ displayed reduced susceptibility to development of resistance in comparison to the parent drug. Low cytotoxicity make the zwitterionic quinolones promising starting points for further optimization towards more potent and safer antibacterial agents. Accordingly, permanent C7 amine quaternization and reduced lipophilicity of quinolones would account for reduced distribution to the CNS and mammalian cells, as well as atypical pharmacokinetics.

\section{Experimental section}

\subsection{General information}

Chemicals were obtained from Acros Organics or Sigma-Aldrich and used without further purification. Analytical TLC was performed on silica gel Merck 60 F254 plates $(0.25 \mathrm{~mm})$ with UV light visualisation. The ${ }^{1} \mathrm{H}$ NMR spectra were obtained using Varian Mercury-VX $300 \mathrm{MHz}$ spectrometer. ${ }^{1} \mathrm{H}$ NMR data were internally referenced to TMS $(0.0 \mathrm{ppm})$ or DMSO-d $(2.5 \mathrm{ppm})$. The IR (KBr) spectra were recorded on Thermo Scientific Nicolet 380 FT-IR spectrometer. The mass spectra were recorded on Shimadzu single quadrupole LCMS $2010 \mathrm{eV}$ mass spectrometer. Melting points were determined on a X-4 melting point apparatus with microscope and were uncorrected. Isoxazolones $\mathbf{1}$ and $\mathbf{2}$ were synthesized according to the previously described synthetic routes. Hence, substrate 1 was obtained via condensation of $N$-hydroxy-3-(hydroxyamino)-3-iminopropanamide with acetylacetone in the presence of piperidne [35], while $\mathbf{2}$ was synthesized through in multi-step procedure from aniline [36]. 


\subsection{Synthetic procedures}

4.2.1. General procedure for the synthesis of 8-carboxy-5,7-dimethyl-3H-spiro[ $[1,2,4]$ triazolo[4,3-a]pyridine-2,1'-piperazin]-1'-ium chlorides (3a-h)

4,6-Dimethylisoxazolo[3,4- $b$ ]pyridin-3(1H)-one (1) $(0.150 \mathrm{~g}, 0.91 \mathrm{mmol}), 35 \mathrm{wt} \%$ solution of formaldehyde $(0.340 \mathrm{~mL}, 3.64 \mathrm{mmol})$ and the appropriate fluoroquinolone $(0.61 \mathrm{mmol})$ or fluoroquinolone hydrochloride $(0.61 \mathrm{mmol})$ and triethylamine $(0.067 \mathrm{ml}, 0.45 \mathrm{mmol})$ were dissolved in methanol $(20 \mathrm{~mL})$ and $\mathrm{DMF}(5 \mathrm{~mL})$. The reaction mixture was heated for $1 \mathrm{~h}$ at $50^{\circ} \mathrm{C}$. The progress of the reaction was monitored with TLC (chloroform/methanol 9:1 v/v) and LC-MS (methanol/acetonitrile $1: 1 \mathrm{v} / \mathrm{v}$ ). After $12 \mathrm{~h}$ the precipitated product was filtered off and washed with acetone $(3 \times 3 \mathrm{~mL})$. The filtrate was evaporated under reduced pressure and the product was recrystalized from methanol/dichloromethane (1:9) mixture for compounds 3a-e,g,h or isolated by HPLC purification (column SunFire Prep C18 OBD, $10 \mu \mathrm{m}, 30 \times 250 \mathrm{~mm}$, Waters; elution phase: acetonitrile/water 5:95 with $0.1 \%$ acetic acid) for compound $3 \mathbf{f}$. The obtained 5,7-dimethyl-3H-spiro[ $[1,2,4]$ triazolo[4,3-a]pyridine-2,1'-piperazin]-9-ium-8-carboxylates were converted quantitatively into the hydrochlorides with methanolic solution of $\mathrm{HCl}$.

4.2.1.1. 8-Carboxy-4'-(6-carboxy-8-ethyl-5-oxo-5,8-dihydropyrido[2,3-d]pyrimidin-2-yl)-5,7dimethyl-3H-spiro[ [1,2,4]triazolo[4,3-a]pyridine-2,1'-piperazin]-1'-ium chloride (3a)

Synthesized from pipemidic acid. Yield: $72 \%(0.233 \mathrm{~g})$; $\mathrm{mp} 236-238^{\circ} \mathrm{C}$; IR (KBr): $3420,3047,1707$, 1626, 1543, 1473, 1444, 1371, 1264, 1183, 1118, 969, 815, 716, 607, $530 \mathrm{~cm}^{-1}$; ${ }^{1} \mathrm{H}$ NMR (300 MHz, DMSO-d $\left.d_{6}\right): \delta=1.36\left(\mathrm{t}, J=7.1 \mathrm{~Hz}, 3 \mathrm{H}, \mathrm{CH}_{3}\right), 2.25\left(\mathrm{~s}, 3 \mathrm{H}, \mathrm{CH}_{3}\right), 2.32\left(\mathrm{~s}, 3 \mathrm{H}, \mathrm{CH}_{3}\right), 3.86-3.95(\mathrm{~m}, 4 \mathrm{H}$, $\left.\mathrm{CH}_{2}\right), 4.23-3.28\left(\mathrm{~m}, 2 \mathrm{H}, \mathrm{CH}_{2}\right), 4.45$ (q, $\left.J=7.1 \mathrm{~Hz}, 2 \mathrm{H}, \mathrm{CH}_{2}\right), 4.47-4.52\left(\mathrm{~m}, 2 \mathrm{H}, \mathrm{CH}_{2}\right), 5.97$ (s, 2H, $\mathrm{CH}_{2}$ ), 6.20 (s, 1H, CH), 9.02 (s, 1H, CH), 9.31 (s, H, CH), 13.29 (bs, 1H, OH), 14.65 (bs, 1H, OH); MS (ESI) $m / z: 480[\mathrm{M}]^{+}$; elemental analysis calcd (\%) for $\mathrm{C}_{23} \mathrm{H}_{26} \mathrm{ClN}_{7} \mathrm{O}_{5} \mathrm{xH}_{2} \mathrm{O}: \mathrm{C} 51.72, \mathrm{H} 5.29, \mathrm{~N}$ 18.36; found C 51.39, H 5.02, N 18.08 .

4.2.1.2. 8-Carboxy-4'-(6-carboxy-8-ethyl-3-fluoro-5-oxo-5,8-dihydro-1,8-naphthyridin-2-yl)-5,7dimethyl-3H-spiro[ [1,2,4]triazolo[4,3-a]pyridine-2,1'-piperazin]-1'-ium chloride (3b)

Synthesized from enoxacin. Yield: $36 \%$ (0.132 g); mp 209-210.5 ${ }^{\circ} \mathrm{C}$; IR (KBr): 3413, 2987, 1711 , 1629, 1561, 1480, 1444, 1375, 1269, 1178, 1106, 1048, 972, 808, 744, 690, 600, $497 \mathrm{~cm}^{-1}$; ${ }^{1} \mathrm{H} \mathrm{NMR}$ (300 MHz, DMSO- $\left.d_{6}\right): \delta=1.40\left(\mathrm{t}, J=5.8 \mathrm{~Hz}, 3 \mathrm{H}, \mathrm{CH}_{3}\right), 2.25\left(\mathrm{~s}, 3 \mathrm{H}, \mathrm{CH}_{3}\right), 2.32\left(\mathrm{~s}, 3 \mathrm{H}, \mathrm{CH}_{3}\right), 3.80-$ $3.87\left(\mathrm{~m}, 2 \mathrm{H}, \mathrm{CH}_{2}\right), 3.99-4.03\left(\mathrm{~m}, 2 \mathrm{H}, \mathrm{CH}_{2}\right), 4.11-4.18\left(\mathrm{~m}, 2 \mathrm{H}, \mathrm{CH}_{2}\right), 4.54\left(\mathrm{q}, J=5.8 \mathrm{~Hz}, 2 \mathrm{H}, \mathrm{CH}_{2}\right)$, $5.95\left(\mathrm{~s}, 2 \mathrm{H}, \mathrm{CH}_{2}\right), 6.20(\mathrm{~s}, 1 \mathrm{H}, \mathrm{CH}), 8.22\left(\mathrm{~d}, J_{H F}=13.1 \mathrm{~Hz}, 1 \mathrm{H}, \mathrm{CH}\right), 9.03(\mathrm{~s}, 1 \mathrm{H}, \mathrm{CH}), 13.12(\mathrm{bs}$, $1 \mathrm{H}, \mathrm{OH}), 15.15$ (bs, 1H OH); MS (ESI) $\mathrm{m} / z: 497[\mathrm{M}]^{+}$; elemental analysis calcd (\%) for $\mathrm{C}_{24} \mathrm{H}_{26} \mathrm{ClFN}_{6} \mathrm{O}_{5} \times 3.5 \mathrm{H}_{2} \mathrm{O}$ : C 48.36, H 5.58, N 14.10; found C 48.54, H 5.01, N 14.07.

4.2.1.3. 8-Carboxy-4'-(3-carboxy-1-ethyl-6-fluoro-4-oxo-1,4-dihydroquinolin-7-yl)-5,7-dimethyl3 H-spiro[ [1,2,4]triazolo[4,3-a]pyridine-2,1'-piperazin]-1'-ium chloride (3c)

Synthesized from norfloxacin. Yield: 36\% (0.212 g); mp 206-208 ${ }^{\circ} \mathrm{C}$; IR (KBr): 3422, 2985, 1716 , $1628,1564,1483,1386,1272,1177,1029,973,806,751,694,599,499 \mathrm{~cm}^{-1}$; ${ }^{1} \mathrm{H}$ NMR (300 MHz, 
DMSO- $\left.d_{6}\right): \delta=1.42\left(\mathrm{t}, J=7.0 \mathrm{~Hz}, 3 \mathrm{H}, \mathrm{CH}_{3}\right), 2.24\left(\mathrm{~s}, 3 \mathrm{H}, \mathrm{CH}_{3}\right), 3.32\left(\mathrm{~s}, 3 \mathrm{H}, \mathrm{CH}_{3}\right), 3.81-3.88(\mathrm{~m}, 8 \mathrm{H}$, $\left.\mathrm{CH}_{2}\right), 4.63$ (q, $\left.J=7.0 \mathrm{~Hz}, 2 \mathrm{H}, \mathrm{CH}_{2}\right), 5.96\left(\mathrm{~s}, 2 \mathrm{H}, \mathrm{CH}_{2}\right), 6.20(\mathrm{~s}, 1 \mathrm{H}, \mathrm{CH}), 7.34\left(\mathrm{~d},{ }^{4} J_{H F}=7.0 \mathrm{~Hz}, 1 \mathrm{H}\right.$, $\mathrm{CH}), 7.99\left(\mathrm{~d},{ }^{3} J_{H F}=12.9 \mathrm{~Hz}, 1 \mathrm{H}, \mathrm{CH}\right), 8.98(\mathrm{~s}, 1 \mathrm{H}, \mathrm{CH})$; MS (ESI) $m / z: 496[\mathrm{M}]^{+}$; elemental analysis calcd (\%) for $\mathrm{C}_{25} \mathrm{H}_{27} \mathrm{ClFN}_{5} \mathrm{O}_{5} \times 6 \mathrm{H}_{2} \mathrm{O}$ : C 49.91, H 6.14, N 10.94; found: C 49.85, H 6.22, N 10.88.

4.2.1.4. 8-Carboxy-4'-(3-carboxy-1-ethyl-6,8-difluoro-4-oxo-1,4-dihydroquinolin-7-yl)-2',5,7trimethyl-3H-spiro[ [1,2,4]triazolo[4,3-a]pyridine-2,1'-piperazin]-1'-ium chloride (3d)

Synthesized from lomefloxacin hydrochloride. Yield: $28 \%(0.101 \mathrm{mg}) ; \mathrm{mp} 219-222{ }^{\circ} \mathrm{C}$; IR (KBr): 3425, 3050, 2985, 2893, 1718, 1626, 1563, 1525, 1476, 1387, 1284, 1250, 1178, 1088, 1053, 806, 740, $601 \mathrm{~cm}^{-1}$; ${ }^{1} \mathrm{H}$ NMR (300 MHz, DMSO- $\left.d_{6}\right): \delta=1.35\left(\mathrm{~d}, J=6.3 \mathrm{~Hz}, 3 \mathrm{H}, \mathrm{CH}_{3}\right), 1.46(\mathrm{t}, J=6.8 \mathrm{~Hz}$, $\left.3 \mathrm{H}, \mathrm{CH}_{3}\right), 2.25\left(\mathrm{~s}, 3 \mathrm{H}, \mathrm{CH}_{3}\right), 2.38\left(\mathrm{~s}, 3 \mathrm{H}, \mathrm{CH}_{3}\right), 3.56-3.63(\mathrm{~m}, 1 \mathrm{H}, \mathrm{CH}), 3.76-3.80\left(\mathrm{~m}, 2 \mathrm{H}, \mathrm{CH}_{2}\right)$, 3.81-3.84 (m, 2H, CH$), 3.97-4.03\left(\mathrm{~m}, 2 \mathrm{H}, \mathrm{CH}_{2}\right), 4.57-4.62\left(\mathrm{~m}, 2 \mathrm{H}, \mathrm{CH}_{2}\right), 5.97$ (s, 2H, $\left.\mathrm{CH}_{2}\right), 6.18$ (s, 1H, CH), $7.94\left(\mathrm{~d}, J_{H F}=11.9 \mathrm{~Hz}, 2 \mathrm{H}, \mathrm{CH}\right), 8.97(\mathrm{~s}, 1 \mathrm{H}, \mathrm{CH}), 13.35(\mathrm{bs}, 1 \mathrm{H}, \mathrm{OH}), 14.78(\mathrm{bs}, 1 \mathrm{H}$, $\mathrm{OH}$ ); MS (ESI) $m / z: 528[\mathrm{M}]^{+}$; elemental analysis calcd (\%) for $\mathrm{C}_{26} \mathrm{H}_{28} \mathrm{ClF}_{2} \mathrm{~N}_{5} \mathrm{O}_{5} \times 2 \mathrm{H}_{2} \mathrm{O}: \mathrm{C} 52.05, \mathrm{H}$ 5.38, N 11.67; found: C 51.46, H 5.26, N 12.00.

4.2.1.5. 8-Carboxy-4'-(3-carboxy-1-cyclopropyl-6-fluoro-4-oxo-1,4-dihydroquinolin-7-yl)-5,7dimethyl-3H-spiro[ [1,2,4]triazolo[4,3-a]pyridine-2,1'-piperazin]-1'-ium chloride (3e)

Synthesized from ciprofloxacin. Yield: 51\% (0.187 g); mp 219-221 ${ }^{\circ} \mathrm{C}$; IR (KBr): 3421, 2925, 2855, 1716, 1629, 1561, 1491, 1466, $1269 \mathrm{~cm}-1$; ${ }^{1} \mathrm{H}$ NMR (300 MHz, DMSO-d $): \delta=1.19-1.21(\mathrm{~m}, 2 \mathrm{H}$, $\mathrm{CH}_{2}$ ), 1.19-1.21 (m, 2H, CH 2$), 2.25$ (s, 3H, CH $), 2.33$ (s, 3H, $\left.\mathrm{CH}_{3}\right), 3.81-3.89$ (m, 8H, $\left.\mathrm{CH}_{2}\right), 4.06-$ $4.06(\mathrm{~m}, 1 \mathrm{H}, \mathrm{CH}), 5.96\left(\mathrm{~s}, 2 \mathrm{H}, \mathrm{CH}_{2}\right), 6.20(\mathrm{~s}, 1 \mathrm{H}, \mathrm{CH}), 7.68\left(\mathrm{~d},{ }^{4} J_{H F}=7.6 \mathrm{~Hz}, 1 \mathrm{H}, \mathrm{CH}\right), 7.98(\mathrm{~d}$, $\left.{ }^{3} J_{H F}=12.9 \mathrm{~Hz}, 1 \mathrm{H}, \mathrm{CH}\right), 8.69(\mathrm{~s}, 1 \mathrm{H}, \mathrm{CH}), 15.09$ (bs, $\left.1 \mathrm{H}, \mathrm{OH}\right)$; MS (ESI) $m / z: 508$ [M]+; elemental analysis calcd (\%) for $\mathrm{C}_{16} \mathrm{H}_{19} \mathrm{~N}_{3} \mathrm{O}_{2} \times 3 \mathrm{H}_{2} \mathrm{O}$ : C 52.22, H 5.56, N 11.71; found: C 52.02, H 5.40, N 11.28.

4.2.1.6. 4'-(5-Amino-3-carboxy-1-cyclopropyl-6,8-difluoro-4-oxo-1,4-dihydroquinolin-7-yl)-8carboxy-2',5,6',7-tetramethyl-3H-spiro[ $\quad[1,2,4]$ triazolo[4,3-a]pyridine-2,1'-piperazin]-1'-ium chloride (3f)

Synthesized from sparfloxacin. Yield: $26 \%(0.108 \mathrm{~g}) ; \mathrm{mp} 209^{\circ} \mathrm{C}$ (with decomposition); IR (KBr): 3414, 2975, 2993, 1718, 1632, 1563, 1535, 1518, 1439, 1323, 1298, 1170, 1091, 1039, 508, $758 \mathrm{~cm}^{-1}$; ${ }^{1} \mathrm{H}$ NMR (300 MHz, CD $\left.3 \mathrm{OD}\right): \delta=1.17-1.24\left(\mathrm{~m}, 4 \mathrm{H}, \mathrm{CH}_{2}\right), 1.43\left(\mathrm{~s}, 3 \mathrm{H}, \mathrm{CH}_{3}\right), 1.45\left(\mathrm{~s}, 3 \mathrm{H}, \mathrm{CH}_{3}\right), 2$ $38^{*}$ and $2.42 *\left(\mathrm{~s}, 3 \mathrm{H}, \mathrm{CH}_{3}\right), 2.44^{*}$ and $2.52^{*}\left(\mathrm{~s}, 3 \mathrm{H}, \mathrm{CH}_{3}\right), 3.53-3.80\left(\mathrm{~m}, 4 \mathrm{H}, \mathrm{CH}_{2}\right), 4.00-4.06(\mathrm{~m}$, $1 \mathrm{H}, \mathrm{CH}), 4.14-4.24(\mathrm{~m}, 2 \mathrm{H}, \mathrm{CH}), 5.91^{*}$ and 5.96* $\left(\mathrm{s}, 2 \mathrm{H}, \mathrm{CH}_{2}\right), 6.20^{*}$ and $6.23^{*}(\mathrm{~s}, 1 \mathrm{H}, \mathrm{CH}), 8.00$ and $8.01(\mathrm{~s}, 1 \mathrm{H}, \mathrm{CH})$; $\mathrm{MS}(\mathrm{ESI}) \mathrm{m} / z: 569[\mathrm{M}]^{+}$; ]+; elemental analysis calcd (\%) for $\mathrm{C}_{28} \mathrm{H}_{31} \mathrm{ClF}_{2} \mathrm{~N}_{6} \mathrm{O}_{5} \mathrm{X} 4 \mathrm{H}_{2} \mathrm{O}$ : C 49.67, H 5.81, N 12.41; found: C 49.60, H 5.43, N 12.20.

4.2.1.7. 8-Carboxy-4'-(3-carboxy-1-cyclopropyl-6-fluoro-8-methoxy-4-oxo-1,4-dihydroquinolin-7yl)-2',5,7-trimethyl-3H-spiro[ [1,2,4]triazolo[4,3-a]pyridine-2,1'-piperazin]-1'-ium chloride (3g)

Synthesized from gatifloxacin. Yield: $35 \%$ (0.138 g); mp 195-197 ${ }^{\circ} \mathrm{C}$; IR (KBr): 3422, 2937, 1720 , $1621,1563,1511,1450,1387,1320,1277,1182,1057,937,807,599,550,478 \mathrm{~cm}^{-1} ;{ }^{1} \mathrm{H}$ NMR (300 MHz, DMSO- $\left.d_{6}\right): \delta=1.05-1.14\left(\mathrm{~m}, 4 \mathrm{H}, \mathrm{CH}_{2}\right), 1.27^{*}$ and $1.35^{*}\left(\mathrm{~d}, J=6,2 \mathrm{~Hz}, 3 \mathrm{H}, \mathrm{CH}_{3}\right), 2.24 *$ 
and $2.25^{*}\left(\mathrm{~s}, 3 \mathrm{H} . \mathrm{CH}_{3}\right), 2.36^{*}$ and $2.41^{*}\left(\mathrm{~s}, 3 \mathrm{H} . \mathrm{CH}_{3}\right), 3.62-3.78\left(\mathrm{~m}, 4 \mathrm{H}, \mathrm{CH}_{2}\right), 3.83^{*}$ and $3.86^{*}$ (s, $\left.3 \mathrm{H}, \mathrm{OCH}_{3}\right), 4.05-4.08(\mathrm{~m}, 1 \mathrm{H}, \mathrm{CH}), 4.17-4.19(\mathrm{~m}, 1 \mathrm{H}, \mathrm{CH}), 5.81-6.08\left(\mathrm{~m}, 2 \mathrm{H}, \mathrm{CH}_{2}\right), 7.82(\mathrm{~d}$, $\left.J_{H F}=12.0 \mathrm{~Hz}, 1 \mathrm{H}, \mathrm{CH}\right), 8.72(\mathrm{~s}, 1 \mathrm{H}, \mathrm{CH})$; MS (ESI) $\mathrm{m} / \mathrm{z}: 552[\mathrm{M}]^{+}$; elemental analysis calcd (\%) for $\mathrm{C}_{28} \mathrm{H}_{31} \mathrm{ClFN}_{5} \mathrm{O}_{6} \times 3 \mathrm{H}_{2} \mathrm{O}$ : C 52.38, H 5.81, N 10.91; found: C 52.20, H 5.45, N 10.88.

4.2.1.8. 8-Carboxy-6'-(3-carboxy-1-cyclopropyl-6-fluoro-8-methoxy-4-oxo-1,4-dihydroquinolin-7yl)-5,7-dimethyl-2',3',4',4a',5',6',7',7a'-octahydro-3H-spiro[ $\quad[1,2,4]$ triazolo[4,3-a]pyridine-2,1'pyrrolo[3,4-b]pyridin]-1'-ium chloride (3h)

Synthesized from moxifloxacin hydrochloride. Yield: $0.085 \mathrm{~g}(20 \%)$; mp $190-191{ }^{\circ} \mathrm{C}$; IR (KBr): 3416, 3072, 2948, 2892, 1720, 1621, 1563, 1510, 1445, 1371, 1355, 1320, 1174, 1054, 1033, 806, $484 \mathrm{~cm}^{-1} ;{ }^{1} \mathrm{H}$ NMR (300 MHz, DMSO-d6): $\delta=0.93-0.98(\mathrm{~m}, 1 \mathrm{H}, \mathrm{CH}), 1.01-1.10\left(\mathrm{~m}, 2 \mathrm{H}, \mathrm{CH}_{2}\right)$, 1.16-1.21 (m, 2H, CH$), 1.60-1.67\left(\mathrm{~m}, 2 \mathrm{H}, \mathrm{CH}_{2}\right), 1.86-2.03\left(\mathrm{~m}, 2 \mathrm{H}, \mathrm{CH}_{2}\right), 2.17 *$ and 2.24* (s, 3H, $\left.\mathrm{CH}_{3}\right), 2.29 *$ and 2.83* (s, 3H, $\left.\mathrm{CH}_{3}\right), 3.56\left(\mathrm{~s}, 3 \mathrm{H}, \mathrm{OCH}_{3}\right), 3.80-3.96\left(\mathrm{~m}, 6 \mathrm{H}, \mathrm{CH}_{2}\right), 4.12-4.20(\mathrm{~m}, 1 \mathrm{H}$, $\left.\mathrm{CH}_{2}\right), 4.54-4.68(\mathrm{~m}, 1 \mathrm{H}, \mathrm{CH}), 5.80-6.08\left(\mathrm{~m}, 2 \mathrm{H}, \mathrm{CH}_{2}\right), 6.14^{*}$ and 6.16* (s. 1H, $\left.\mathrm{CH}\right), 7.66^{*}$ and 7.73* $\left(\mathrm{d}, J_{H F}=13.8 \mathrm{~Hz}, 1 \mathrm{H}, \mathrm{CH}\right), 8.64 *$ and $8.67 *(\mathrm{~s}, 1 \mathrm{H}, \mathrm{CH})$; MS (ESI) $m / z: 578[\mathrm{M}]^{+}$; elemental analysis calcd (\%) for $\mathrm{C}_{30} \mathrm{H}_{33} \mathrm{ClFN}_{5} \mathrm{O}_{6} \times 5 \mathrm{H}_{2} \mathrm{O}$ : C 51.17, H 6.16, N 9.95; found: C 50.72, H 5.91, N 9.79.

4.2.2. General procedure for the synthesis of 4-carboxy-1H-spiro[ $[1,2,4]$ triazolo[4,3a]quinoline-2,1'-piperazin]-1'-ium chlorides (4a-h)

Isoxazolo[3,4-b]quinolin-3(1H)-one (2) $(0.100 \mathrm{~g}, 0.54 \mathrm{mmol}), 35 \mathrm{wt} \%$ solution of formaldehyde $(0.202 \mathrm{~mL}, 3.64 \mathrm{mmol})$ and the appropriate fluoroquinolone $(0.54 \mathrm{mmol})$ or fluoroquinolone hydrochloride $(0.54 \mathrm{mmol})$ and triethylamine $(0.075 \mathrm{~mL}, 0.54 \mathrm{mmol})$ were dissolved in methanol $(25 \mathrm{~mL})$ at the room temperature. The progress of the reaction was monitored with TLC (chloroform/methanol 9:1 v/v) and LC-MS (methanol/acetonitrile 1:1 v/v). After $12 \mathrm{~h}$ the reaction mixture was evaporated under reduced pressure and the product was washed with acetone $(3 \times 3 \mathrm{~mL})$. The obtained $1 H$-spiro[ [1,2,4]triazolo[4,3-a]quinoline-2,1'-piperazin]-11-ium-4-carboxylates were converted quantitatively into the corresponding hydrochlorides with methanolic solution of $\mathrm{HCl}$.

4.2.2.1. 4-Carboxy-4'-(6-carboxy-8-ethyl-5-oxo-5,8-dihydropyrido[2,3-d]pyrimidin-2-yl)-1Hspiro[ [1,2,4]triazolo[4,3-a]quinoline-2,1'-piperazin]-1'-ium chloride (4a). Synthesized from pipemidic acid

Yield: 73\% (0.235 g); $\mathrm{mp} 231-232.5^{\circ} \mathrm{C}$; IR (KBr): 3418, 2925, 2854, 1719, 1621, 1572, 1541, 1516, 1443, 1369, 1261, 1212, 1170, 1117, 816, $592 \mathrm{~cm}^{-1}$; ${ }^{1} \mathrm{H}$ NMR $\left(300 \mathrm{MHz}, \mathrm{DMSO}-d_{6}\right): \delta=1.38(\mathrm{t}$, $\left.J=7.1 \mathrm{~Hz}, 3 \mathrm{H}, \mathrm{CH}_{3}\right), 4.01-4.07\left(\mathrm{~m}, 4 \mathrm{H}, \mathrm{CH}_{2}\right), 4.36-4.50\left(\mathrm{~m}, 4 \mathrm{H}, \mathrm{CH}_{2}\right), 4.47\left(\mathrm{q}, J=7.1 \mathrm{~Hz}, 2 \mathrm{H}, \mathrm{CH}_{2}\right)$, $6.05\left(\mathrm{~s}, 2 \mathrm{H}, \mathrm{CH}_{2}\right), 7.25(\mathrm{~d}, J=7.9 \mathrm{~Hz}, 1 \mathrm{H}, \mathrm{CH}), 7.39(\mathrm{t}, J=7.9 \mathrm{~Hz}, 1 \mathrm{H}, \mathrm{CH}), 7.82(\mathrm{t}, J=7.9 \mathrm{~Hz}, 1 \mathrm{H}$, $\mathrm{CH}), 8.01(\mathrm{~d}, J=7.9 \mathrm{~Hz}, 1 \mathrm{H}, \mathrm{CH}), 8.75$ (s, 1H, CH), 9.0 (s, 1H, CH), 9.33 (s, 1H, CH); MS (ESI) $m / z: 502[\mathrm{M}]^{+}$; elemental analysis calcd $(\%)$ for $\mathrm{C}_{25} \mathrm{H}_{24} \mathrm{ClN}_{7} \mathrm{O}_{5} \times 3.5 \mathrm{H}_{2} \mathrm{O}: \mathrm{C} 49.96, \mathrm{H} 5.20, \mathrm{~N} 16.31$; found: C 49.48, H 4.95, N 16.21.

4.2.2.2. 4-Carboxy-4'-(6-carboxy-8-ethyl-3-fluoro-5-oxo-5,8-dihydro-1,8-naphthyridin-2-yl)-1Hspiro[ [1,2,4]triazolo[4,3-a]quinoline-2,1'-piperazin]-1'-ium chloride (4b) 
Synthesized from enoxacin. Yield: $74 \%(0.243 \mathrm{~g})$; $\mathrm{mp} 227.5-229.5^{\circ} \mathrm{C}$; IR (KBr): $3418,2925,1711$, 1626, 1573, 1549, 1477, 1448, 1378, 1272, 1210, 1168, 1105, 808, 745, 592, 499, $459 \mathrm{~cm}^{-1}$; ${ }^{1} \mathrm{H}$ NMR (300 MHz, DMSO-d6): $\delta=1.41\left(\mathrm{t}, J=7.3 \mathrm{~Hz}, 3 \mathrm{H}, \mathrm{CH}_{3}\right), 3.99-4.13\left(\mathrm{~m}, 4 \mathrm{H}, \mathrm{CH}_{2}\right), 4.28-4.32(\mathrm{~m}, 4 \mathrm{H}$, $\mathrm{CH}_{2}$ ), 4.57 (q, J=7.3 Hz, 2H, $\left.\mathrm{CH}_{2}\right), 6.04\left(\mathrm{~s}, 2 \mathrm{H}, \mathrm{CH}_{2}\right), 7.24$ (d, J=8.2 Hz, 1H, CH), 7.39 (t, $J=8.2 \mathrm{~Hz}, 1 \mathrm{H}, \mathrm{CH}), 7.82(\mathrm{t}, J=8.2 \mathrm{~Hz}, 1 \mathrm{H}, \mathrm{CH}), 8.01(\mathrm{~d}, J=8.2 \mathrm{~Hz}, 1 \mathrm{H}, \mathrm{CH}), 8.24\left(\mathrm{~d}, J_{H F}=12.9 \mathrm{~Hz}\right.$, $1 \mathrm{H}, \mathrm{CH}), 8.75$ (s, 1H, CH), $9.04(\mathrm{~s}, 1 \mathrm{H}, \mathrm{CH}), 9.49$ (bs, 1H, OH), 15.14 (bs, 1H, OH); MS (ESI) $\mathrm{m} / z$ : $519[\mathrm{M}]^{+}$; elemental analysis calcd $(\%)$ for $\mathrm{C}_{26} \mathrm{H}_{24} \mathrm{ClFN}_{6} \mathrm{O}_{5} \mathrm{X}_{3} \mathrm{H}_{2} \mathrm{O}$ : C 51.28, H 4.97, N 13.80; found: C 51.02, H 4.65, N 13.80.

\subsubsection{4-Carboxy-4'-(3-carboxy-1-ethyl-6-fluoro-4-oxo-1,4-dihydroquinolin-7-yl)-1H-spiro[ [1,2,4]triazolo[4,3-a]quinoline-2,1'-piperazin]-1'-ium chloride (4c)}

Synthesized from norfloxacin. Yield: 93\% (0.313 g); mp 244-245 ${ }^{\circ} \mathrm{C}$; IR (KBr): 3423, 2979, 1715 , $1625,1573,1548,1460,1389.1270,1215,750 \mathrm{~cm}^{-1} ;{ }^{1} \mathrm{H}$ NMR $\left(300 \mathrm{MHz}, \mathrm{DMSO}-d_{6}\right): \delta=1.44(\mathrm{t}$, $\left.J=7.1 \mathrm{~Hz}, 3 \mathrm{H}, \mathrm{CH}_{3}\right), 3.84-3.91\left(\mathrm{~m}, 4 \mathrm{H}, \mathrm{CH}_{2}\right), 3.97-4.20\left(\mathrm{~m}, 4 \mathrm{H}, \mathrm{CH}_{2}\right), 4.65\left(\mathrm{q}, J=7.1 \mathrm{~Hz}, 2 \mathrm{H}, \mathrm{CH}_{2}\right)$, $6.03\left(\mathrm{~s}, 2 \mathrm{H}, \mathrm{CH}_{2}\right), 7.22(\mathrm{~d}, J=8.2 \mathrm{~Hz}, 1 \mathrm{H}, \mathrm{CH}), 7.37-7.42(\mathrm{~m}, 2 \mathrm{H}, \mathrm{CH}), 7.82(\mathrm{t}, J=8.2 \mathrm{~Hz}, 1 \mathrm{H}, \mathrm{CH})$, $8.00(\mathrm{~d}, J=5.3 \mathrm{~Hz}, 1 \mathrm{H}, \mathrm{CH}), 8.03(\mathrm{~s}, 1 \mathrm{H}, \mathrm{CH}), 8.75(\mathrm{~s}, 1 \mathrm{H}, \mathrm{CH}), 8.99(\mathrm{~s}, 1 \mathrm{H}, \mathrm{CH})$; MS (ESI) $m / z$ : $518[\mathrm{M}]^{+}$; elemental analysis calcd $(\%)$ for $\mathrm{C}_{27} \mathrm{H}_{25} \mathrm{ClFN}_{5} \mathrm{O}_{5} \mathrm{X} 4 \mathrm{H}_{2} \mathrm{O}$ : C 51.80, H 5.31, N 11.19; found: C 51.58, H 4.94, N 11.22.

\subsubsection{4-Carboxy-4'-(3-carboxy-1-ethyl-6,8-difluoro-4-oxo-1,4-dihydroquinolin-7-yl)-2'-methyl- $1 H$-spiro[ [1,2,4]triazolo[4,3-a]quinoline-2,1'-piperazin]-1'-ium chloride (4d)}

Synthesized from lomefloxacin hydrochloride. Yield: $86 \% \quad(0.295 \mathrm{~g}) ; \mathrm{mp} \quad 276{ }^{\circ} \mathrm{C}$ (with decomposition); IR (KBr): 6045, 3139, 3048, 1723, 1621, 1573, 1525, 1455, 1395, 1329, 1253, 1206, 1088, 1050, 1021, 932, 807, $739 \mathrm{~cm}^{-1}$; ${ }^{1} \mathrm{H}$ NMR (300 MHz, DMSO- $\left.d_{6}\right): \delta=1.29(\mathrm{t}, J=6.5 \mathrm{~Hz}, 3 \mathrm{H}$, $\left.\mathrm{CH}_{3}\right), 1.44-1.47\left(\mathrm{~m}, 3 \mathrm{H}, \mathrm{CH}_{3}\right), 3.71-3.87\left(\mathrm{~m}, 4 \mathrm{H}, \mathrm{CH}_{2}\right), 3.94-4.00(\mathrm{~m}, 1 \mathrm{H}, \mathrm{CH}), 4.07-4.14(\mathrm{~m}, 2 \mathrm{H}$, $\left.\mathrm{CH}_{2}\right), 4.57-4.60\left(\mathrm{~m}, 2 \mathrm{H}, \mathrm{CH}_{2}\right), 5.86-6.21\left(\mathrm{~m}, 2 \mathrm{H}, \mathrm{CH}_{2}\right), 7.40$ (d, J=7.6 Hz, 1H, CH), 7.80-7.97 (m, $3 \mathrm{H}, \mathrm{CH}), 8.01(\mathrm{~d}, J=8.2 \mathrm{~Hz}, 1 \mathrm{H}, \mathrm{CH}), 8.73(\mathrm{~s}, 1 \mathrm{H}, \mathrm{CH}), 8.95\left(\mathrm{~d}, J_{H F}=8.2 \mathrm{~Hz}, 1 \mathrm{H}, \mathrm{CH}\right) 8.97(\mathrm{~s}, 1 \mathrm{H}$, $\mathrm{CH}), 9.81$ (bs, 1H, OH), 9.69 (bs, 1H, OH); MS (ESI) m/z: $550[\mathrm{M}]^{+}$; elemental analysis calcd (\%) for $\mathrm{C}_{28} \mathrm{H}_{26} \mathrm{ClF}_{2} \mathrm{~N}_{5} \mathrm{O}_{5} \times 3 \mathrm{H}_{2} \mathrm{O}$ : C 52.54, H 5.04, N 10.94; found: C 52.36, H 5.19, N 10.82.

4.2.2.5. 4-Carboxy-4'-(3-carboxy-1-cyclopropyl-6-fluoro-4-oxo-1,4-dihydroquinolin-7-yl)-1Hspiro[ [1,2,4]triazolo[4,3-a]quinoline-2,1'-piperazin]-1'-ium chloride (4e)

Synthesized from ciprofloxacin. Yield: $91 \%(0.307 \mathrm{~g})$; $\mathrm{mp} 249-251{ }^{\circ} \mathrm{C}$; IR (KBr): $3421,3059,1717$, $1625,1573,1547,1492,1459,1268,1217,1170,952,806,748,707,593,462 \mathrm{~cm}^{-1}$; ${ }^{1} \mathrm{H}$ NMR (300 MHz, DMSO- $\left.d_{6}\right): \delta=1.18-1.23\left(\mathrm{~m}, 2 \mathrm{H}, \mathrm{CH}_{2}\right), 1.28-1.37\left(\mathrm{~m}, 2 \mathrm{H}, \mathrm{CH}_{2}\right), 3.54-3.58(\mathrm{~m}, 1 \mathrm{H}, \mathrm{CH})$, 4.88-4.90 (m, 4H, CH$), 4.02-4.06\left(\mathrm{~m}, 2 \mathrm{H}, \mathrm{CH}_{2}\right), 4.18-4.22\left(\mathrm{~m}, 2 \mathrm{H}, \mathrm{CH}_{2}\right), 6.05\left(\mathrm{~s}, 2 \mathrm{H}, \mathrm{CH}_{2}\right), 7.24$ $(\mathrm{d}, J=8.2 \mathrm{~Hz}, 1 \mathrm{H}, \mathrm{CH}), 7.39(\mathrm{t}, J=8.2 \mathrm{~Hz}, 1 \mathrm{H}, \mathrm{CH}), 7.72\left(\mathrm{~d},{ }^{4} J_{H F}=7.6 \mathrm{~Hz}, 1 \mathrm{H}, \mathrm{CH}\right), 7.82(\mathrm{t}$, $J=8.2 \mathrm{~Hz}, 1 \mathrm{H}, \mathrm{CH}), 7.99\left(\mathrm{~d},{ }^{3} J_{H F}=12.9 \mathrm{~Hz}, 1 \mathrm{H}, \mathrm{CH}\right), 8.02(\mathrm{~d}, J=8.2 \mathrm{~Hz}, 1 \mathrm{H}, \mathrm{CH}), 8.69(\mathrm{~s}, 1 \mathrm{H}, \mathrm{CH})$, 8.75 (s, 1H, CH), 9.55 (bs, 1H, OH), 15.09 (bs, 1H, OH); MS (ESI) m/z: 530 [M] ; elemental analysis calcd (\%) for $\mathrm{C}_{28} \mathrm{H}_{25} \mathrm{ClFN}_{5} \mathrm{O}_{5} \times 3.5 \mathrm{H}_{2} \mathrm{O}$ : C 53.46, H 5.13, N 11.13; found: C 53.47, H 4.85, N 11.02. 
4.2.2.6. 4'-(5-Amino-3-carboxy-1-cyclopropyl-6,8-difluoro-4-oxo-1,4-dihydroquinolin-7-yl)-4carboxy-2',6'-dimethyl-1H-spiro[ [1,2,4]triazolo[4,3-a]quinoline-2,1'-piperazin]-1'-ium chloride (4f)

Synthesized from sparfloxacin. Yield: $86 \%$ (0.331 g); mp 240-241 ${ }^{\circ} \mathrm{C}$; IR (KBr): 3443, 2985, 1715 , 1626, 1573. 1519, 1439, 1323, 1299, 1208, 1167, 1088, $758 \mathrm{~cm}^{-1} ;{ }^{1} \mathrm{H}$ NMR (300 MHz, DMSO-d 6 ): $\delta=1.13\left(\mathrm{~d}, J=5.9 \mathrm{~Hz}, 4 \mathrm{H}, \mathrm{CH}_{2}\right), 1.26^{*}$ and $1.30^{*}\left(\mathrm{~d}, J=6.4 \mathrm{~Hz}, 6 \mathrm{H}, \mathrm{CH}_{3}\right), 3.6\left(\mathrm{bs}, 2 \mathrm{H}, \mathrm{NH}_{2}\right), 3.73$ $\left(\mathrm{d}, J=6.5 \mathrm{~Hz}, 4 \mathrm{H}, \mathrm{CH}_{2}\right), 4.02-4.04 *$ and $4.33-4.34 *(\mathrm{~m}, 2 \mathrm{H}, \mathrm{CH}), 4.18-4.25(\mathrm{~m}, 1 \mathrm{H}, \mathrm{CH}), 6.07 *$ and 6.13* (s, 2H, CH 2$), 7.40$ (t, $J=8.2 \mathrm{~Hz}, 1 \mathrm{H}, \mathrm{CH}), 7.44(\mathrm{~d}, J=8.2 \mathrm{~Hz}, 1 \mathrm{H}, \mathrm{CH}), 7.84(\mathrm{t}, J=8.2 \mathrm{~Hz}, 1 \mathrm{H}$, $\mathrm{CH}), 8.00(\mathrm{~d}, J=8.2 \mathrm{~Hz}, 1 \mathrm{H}, \mathrm{CH}), 8.54(\mathrm{~s}, 1 \mathrm{H}, \mathrm{CH}), 8.73(\mathrm{~s}, 1 \mathrm{H}, \mathrm{CH})$; MS (ESI) $\mathrm{m} / z: 591[\mathrm{M}]^{+}$; elemental analysis calcd (\%) for $\mathrm{C}_{30} \mathrm{H}_{29} \mathrm{ClF}_{2} \mathrm{~N}_{6} \mathrm{O}_{5} \times 5 \mathrm{H}_{2} \mathrm{O}$ : C 50.25, H 5.48, N 11.72; found: C 50.01, H 5.01, N 11.46.

4.2.2.7. 4-Carboxy-4'-(3-carboxy-1-cyclopropyl-6-fluoro-8-methoxy-4-oxo-1,4-dihydroquinolin-7yl)-2'-methyl-1H-spiro[ [1,2,4]triazolo[4,3-a]quinoline-2,1'-piperazin]-1'-ium chloride (4g)

Synthesized from gatifloxacin. Yield: $91 \%(0.351 \mathrm{~g})$; $\mathrm{mp} 227-229^{\circ} \mathrm{C}$; IR (KBr): 3417, 2942, 1721 , 1620, 1573, 1546, 1510, 1452, 1391, 1320, 1194, 1168, 1059, $807 \mathrm{~cm}^{-1} ;{ }^{1} \mathrm{H}$ NMR (300 MHz, DMSO-d $)): \delta=1.06-1.11\left(\mathrm{~m}, 2 \mathrm{H}, \mathrm{CH}_{2}\right), 1.13-1.15\left(\mathrm{~m}, 2 \mathrm{H}, \mathrm{CH}_{2}\right), 1.31^{*}$ and $1.36^{*}(\mathrm{~d}, J=6.4 \mathrm{~Hz}, 3 \mathrm{H}$, $\left.\mathrm{CH}_{3}\right), 3.61-3.82\left(\mathrm{~m}, 4 \mathrm{H}, \mathrm{CH}_{2}\right), 3.88^{*}$ and 3.90* (s, 3H, $\left.\mathrm{OCH}_{3}\right), 3.94-4.02(\mathrm{~m}, 1 \mathrm{H}, \mathrm{CH}), 4.08-4.12$ (m, 1H, CH), 4.19-4.29 (m, 2H, $\left.\mathrm{CH}_{2}\right), 5.85-6.21\left(\mathrm{~m}, 2 \mathrm{H}, \mathrm{CH}_{2}\right), 7.15-7.43(\mathrm{~m}, 2 \mathrm{H}, \mathrm{CH}), 7.80-7.87$ (m, 2H, CH), $8.01(\mathrm{~d}, J=7.6 \mathrm{~Hz}, 1 \mathrm{H}, \mathrm{CH}), 8.73(\mathrm{~s}, 1 \mathrm{H}, \mathrm{CH}), 8.74(\mathrm{~s}, 1 \mathrm{H}, \mathrm{CH})$; MS (ESI) m/z: 574 $[\mathrm{M}]^{+}$; elemental analysis calcd $(\%)$ for $\mathrm{C}_{30} \mathrm{H}_{29} \mathrm{ClFN}_{5} \mathrm{O}_{6} \times 6 \mathrm{H}_{2} \mathrm{O}$ : C 50.18, H 5.75, N 9.75; found: C 50.06, H 5.79, N 9.56.

4.2.2.8. 4-Carboxy-6'-(3-carboxy-1-cyclopropyl-6-fluoro-8-methoxy-4-oxo-1,4-dihydroquinolin-7yl)-2',3', $4^{\prime}, 4 a^{\prime}, 5^{\prime}, 6^{\prime}, 7^{\prime}, 7 a^{\prime}$-octahydro-1H-spiro[ $\quad[1,2,4]$ triazolo[4,3-a]quinoline-2,1'-pyrrolo[3,4b]pyridin]-1'-ium chloride (4h)

Synthesized from moxifloxacin hydrochloride. Yield: $84 \%(0.383 \mathrm{~g}) ; \mathrm{mp} 208.5-210.5^{\circ} \mathrm{C}$; IR (KBr): 3421, 2934, 2891, 1718, 1620, 1573, 1558, 1508, 1442, 1355, 1319, 1211, 1168. 1111, 1053, 964, 941, 889, 806, 760, $594 \mathrm{~cm}^{-1} ;{ }^{1} \mathrm{H}$ NMR (300 MHz, DMSO- $\left.d_{6}\right): \delta=0.90-0.98(\mathrm{~m}, 1 \mathrm{H}, \mathrm{CH}), 1.01-1.06$ (m, 2H, $\left.\mathrm{CH}_{2}\right), 1.73-1.77\left(\mathrm{~m}, 2 \mathrm{H}, \mathrm{CH}_{2}\right), 1.96-1.96\left(\mathrm{~m}, 2 \mathrm{H}, \mathrm{CH}_{2}\right), 2.08-2.17\left(\mathrm{~m}, 2 \mathrm{H}, \mathrm{CH}_{2}\right), 3.57$ (s, $\left.3 \mathrm{H}, \mathrm{OCH}_{3}\right), 3.80-3.90\left(\mathrm{~m}, 4 \mathrm{H}, \mathrm{CH}_{2}\right), 4.07-4.14\left(\mathrm{~m}, 2 \mathrm{H}, \mathrm{CH}_{2}\right), 4.22-4.33(\mathrm{~m}, 1 \mathrm{H}, \mathrm{CH}), 4.69-4.77(\mathrm{~m}$, $1 \mathrm{H}, \mathrm{CH}), 5.85-6.33\left(\mathrm{~m}, 2 \mathrm{H}, \mathrm{CH}_{2}\right), 7.30-7.36(\mathrm{~m}, 2 \mathrm{H}, \mathrm{CH}), 7.65^{*}$ and $7.71^{*}\left(\mathrm{~d}, J_{H F}=13.8 \mathrm{~Hz}, 1 \mathrm{H}\right.$, $\mathrm{CH}), 7.80(\mathrm{t}, J=8.2 \mathrm{~Hz}, 1 \mathrm{H}, \mathrm{CH}), 7.97(\mathrm{t}, J=8.2 \mathrm{~Hz}, 1 \mathrm{H}, \mathrm{CH}), 8.63(\mathrm{~s}, 1 \mathrm{H}, \mathrm{CH}), 8.67 *$ and $8.72 *$ (s, $1 \mathrm{H}, \mathrm{CH})$; MS (ESI) $m / z: 600[\mathrm{M}]^{+}$; elemental analysis calcd $(\%)$ for $\mathrm{C}_{32} \mathrm{H}_{31} \mathrm{ClFN}_{5} \mathrm{O}_{6} \mathrm{X} 4 \mathrm{H}_{2} \mathrm{O}: \mathrm{C} 54.28$, H 5.55, N 9.89; found: C 54.93, H 5.47, N 9.89.

\subsection{MEKC analysis}

All micellar electrokinetic chromatography (MECK) experiments were carried out with a P/ACE MDQ plus system (Sciex, Framingham, MA, USA) equipment on photodiode array detector (PDA) and controlled by 32 Karat software (version 10.2). The uncoated fused silica capillaries (50 mm i.d., Polymicro Technologies, West Yorkshire, UK) of $60 \mathrm{~cm}$ total length and $50.2 \mathrm{~cm}$ effective length 
was used. The capillary was rinsed with $0.1 \mathrm{M} \mathrm{NaOH}$ for $30 \mathrm{~min}$, ultrapure water for $10 \mathrm{~min}$ and $\mathrm{BGE}$ for $30 \mathrm{~min}$. Before each analysis the capillary was conditioned with BGE for $2 \mathrm{~min}$. Applied pressure for all rinsing operations was $50 \mathrm{psi}$. The analytes were dissolved in BGE at concentration of $100 \mu \mathrm{g} / \mathrm{ml}$ with addition of quinine (micelles marker) and DMSO (EOF marker). Samples were hydrodynamically injected at 5 psi for $5 \mathrm{~s}$. The separations were performed by applying voltage of $20 \mathrm{kV}$ with positive polarity and constants temperatures at $25 \pm 0.1^{\circ} \mathrm{C}$. The BGE consisted of aqueous solution of $50 \mathrm{mM}$ SDS and $120 \mathrm{mM}$ HEPES - $100 \mathrm{mM}$ Tris buffer of pH 7.4. Detection was carried out at 200, and $280 \mathrm{~nm}$ with $8 \mathrm{~Hz}$ probing frequency. The logarithm of retention factor $\log k$ MECK was calculated using equation introduced by Terabe and co-workers [37]:

\subsection{Biological activity}

\subsubsection{Bacterial strains and growth conditions}

Antibacterial activity was tested using eight reference (Staphylococcus aureus ATCC 6538, Staphylococcus aureus MRSA N315, Staphylococcus epidermidis ATCC 14990, Enterococcus hirae ATCC 1052, Bacillus subtilis ATCC 6633, Escherichia coli ATCC 8739, Pseudomonas aeruginosa ATCC 9027, Proteus vulgaris NCTC 4635) and four clinical strains (Staphylococcus aureus MRSA 6347, Staphylococcus epidermidis MRSE 13199, Streptococcus pneumoniae, Serratia marcescens 12795). Clinical strains were isolated from patients hospitalized in St. Wojciech Adalbert Specialist Hospital in Gdańsk (Independent Public Health Care Facility in Gdańsk, Poland). The other microorganisms were sourced from the American Type Culture Collection (ATCC), University Boulevard Manassas, VA, USA.

All bacterial strains were cultured in MH (Muller Hinton) medium with the only exception of Enterococcus hirae strain, which was cultured in BHI (Brain Heart Infusion). Media were purchased from BioMaxima Polska.

\subsubsection{Determination of antibacterial activity}

The minimum inhibitory concentrations (MIC) and the minimum bactericidal concentrations (MBC) of commercial drugs and hybrid agents were determined by microbroth dilution method according to the EUCAST (European Committee for Antimicrobial Susceptibility Testing) [67] and CLSI (Clinical and Laboratory Standards Institute) [68] reference procedure. The assays were carried out against selected reference and clinical strains Gram-positive and Gram-negative bacteria (Table 2). The inoculum size was $1 \times 10^{5}$ to $5 \times 10^{5} \mathrm{CFU} / \mathrm{ml}$. Stock solutions and dilution series of the all test compounds were prepared in $100 \%$ dimethyl sulfoxide (DMSO). Solutions of the test substances were diluted 50-fold in a proper medium, MH or BHI broth, with the bacterial suspension in 96-well plates. The DMSO final concentration in the assays did not exceed $2.0 \%$. The final concentration of the tested compounds ranged from 512 to $0.004 \mu \mathrm{g} / \mathrm{mL}$. Microplates were incubated at $37{ }^{\circ} \mathrm{C}$ for $48 \mathrm{~h}$. The MIC was considered as the lowest concentration of compound that prevented visible growth of bacteria. Additionally, $10 \mu \mathrm{L}$ of suspension from each well without growth were transferred into agar plates to control bacterial viability. Inoculated plates were incubated at $37^{\circ} \mathrm{C}$. After $48 \mathrm{~h}$ bacterial growth was observed, defining $\mathrm{MBC}$ as the ability of the bacteria with inhibited growth to survive. 
The presented results are representative of at least three independent measurements each made in triplicate.

\subsubsection{In vitro inhibitory activity screening and determination of $\mathrm{IC}_{50}$ values on $E$. coli DNA gyrase}

The assay for determining $\mathrm{IC}_{50}$ values (Inspiralis) was performed on black streptavidin-coated 96well microtiter plates (Thermo Scientific Pierce). The plate was first rehydrated with the wash buffer supplied (20 mM Tris- $\mathrm{HCl} \mathrm{pH} 7.6,137 \mathrm{mM} \mathrm{NaCl}, 0.01 \% \mathrm{w} / \mathrm{v} \mathrm{BSA}, 0.05 \% \mathrm{v} / \mathrm{v}$ Tween 20). Biotinylated oligonucleotide in wash buffer was immobilized onto the wells. The excess of oligonucleotide was then washed off and the enzyme assay carried out in the wells ( $5 \mathrm{~min})$. The final reaction volume of $30 \mu \mathrm{L}$ in buffer $(35 \mathrm{mM}$ Tris- $\mathrm{HCl} \mathrm{pH} 7.5,24 \mathrm{mM} \mathrm{KCl}, 4 \mathrm{mM} \mathrm{MgCl} 2,2 \mathrm{mM}$ DTT, $1.8 \mathrm{mM}$ spermidine, $1 \mathrm{mM}$ ATP, $6.5 \% \mathrm{w} / \mathrm{v}$ glycerol, $0.1 \mathrm{mg} / \mathrm{mL}$ albumin) contained $1.5 \mathrm{U}$ of DNA gyrase from $E$. coli, $0.75 \mu \mathrm{g}$ of relaxed pNO1 plasmid, and $3 \mu \mathrm{L}$ of inhibitors solution in 10\% DMSO and $0.008 \%$ Tween ${ }^{\circledR} 20$. The reactions were incubated for $30 \mathrm{~min}$ at $37^{\circ} \mathrm{C}$ and, after addition of the TF buffer ( $50 \mathrm{mM} \mathrm{NaOAc} \mathrm{pH} \mathrm{5.0,50} \mathrm{mM} \mathrm{NaCl}$, and $50 \mathrm{mM} \mathrm{MgCl}_{2}$ ), which terminated the enzymatic reaction, for another $30 \mathrm{~min}$ at room temperature to allow triplex formation (biotin-oligonucleotideplasmid). The unbound plasmid was then washed off using TF buffer, and a solution of SybrGOLD stain in T10 buffer (10 mMTris-HCl pH 8.0 and $1 \mathrm{mM}$ EDTA) was added. After mixing, the fluorescence (excitation $485 \mathrm{~nm}$, emission $535 \mathrm{~nm}$ ) was read using a BioTek Synergy H4 microplate reader. Preliminary screening was performed at inhibitor concentrations of 10 and $1 \mu \mathrm{M}$. IC 50 was determined with seven concentrations of the inhibitors. IC 50 values were calculated using GraphPad Prism software and represent the concentration of inhibitor where the residual activity of the enzyme is $50 \%$ in three independent measurements; the final result is given as their average value. Ciprofloxacin was used as a positive control.

\subsubsection{Determination of antibiofilm activity}

\subsubsection{Biofilm inhibition tests}

The overnight bacterial cultures were diluted 1:10 with the TSB (Tryptic Soy Broth, BioMaxima Polska). The $20 \mu \mathrm{L}$ of inoculum was transferred into 96-well microtiter plates, with $166 \mu \mathrm{L}$ of fresh TSB and $4 \mu \mathrm{L}$ of appropriate compound to obtain a concentration corresponding to $1 / 2 \mathrm{MIC}$, MIC, 2xMIC, 4xMIC. The growth control of bacteria in medium without compounds were also included in the test. After incubation at $37^{\circ} \mathrm{C}$ for $24 \mathrm{~h}$, the supernatants were removed and the plates were washed three times with $200 \mu \mathrm{L}$ sterile normal saline. The surface-attached cells were stained with $200 \mu \mathrm{L}$ of $0.1 \%$ crystal violet for $10 \mathrm{~min}$. The plates were washed 3 times with distilled water and dye was reeluted with $100 \%$ ethanol. Plates were shaken gently, until all crystal violet was dissolved. Absorbance was measured at $570 \mathrm{~nm}$ in Tecan Infinite 200 (Tecan, Männedorf CH) plate reader.

\subsubsection{Biofilm degradation tests}

The overnight bacterial cultures were diluted 1:10 with the TSB. The $20 \mu \mathrm{L}$ of inoculum was transferred into well microtiter plates, with $170 \mu \mathrm{L}$ of fresh TSB and incubated at $37^{\circ} \mathrm{C}$ for $24 \mathrm{~h}$ for biofilm formation. The culture supernatant was discarded and the wells were washed 2 times with 
sterile normal saline to remove nonadherent cells. Then, the wells were filled with combination of fresh TSB medium, compound and bacterial suspension. After incubation for the next $24 \mathrm{~h}$, a procedure for rinsing and staining the biofilm with crystal violet was performed. Absorbance of dissolved dye was measured at $570 \mathrm{~nm}$ in Tecan Infinite 200 plate reader.

\subsubsection{Efflux pump activity assays}

Determination of MIC and MBC against $E$. coli ATCC 8739 were performed as described above with addition of phenylalanine-arginine $\beta$-naphthylamide $(\mathrm{PA} \beta \mathrm{N})$ at final concentration of $50 \mu \mathrm{g} / \mathrm{mL}$.

Fluorescence measurements of cellular accumulation were performed as follows, according to the literature protocol [53]: bacteria E. coli ATCC 8739 were cultured in LB at $37^{\circ} \mathrm{C}$ overnight. A sample of a culture was diluted 50 -fold in LB and incubated at $37^{\circ} \mathrm{C}$ for $1.5-2 \mathrm{~h}$. The resultant mid-log phase cultures were harvested at $4000 \mathrm{rpm}$ for $25 \mathrm{~min}$, washed once with PBS (4000 rpm, $15 \mathrm{~min}$ ), and resuspended in PBS to an $\mathrm{OD}_{600}$ of 2 . Bacteria were treated with $100 \mu \mathrm{M}$ of CCCP (Sigma Aldrich) at $37^{\circ} \mathrm{C}$ for $10 \mathrm{~min}$ and then with the tested compound at the desired concentration at $37^{\circ} \mathrm{C}$ for $0.5 \mathrm{~h}$, washed with $1 \mathrm{~mL}$ of cold water 4 times $\left(13000 \mathrm{rpm}, 4^{\circ} \mathrm{C}, 7 \mathrm{~min}\right)$. To avoid background noise, the flat-bottom black 96-well microplates (Greiner Bio-One, Germany) were used for fluorescence intensity measurements. Bacteria cell pellets were transferred into 96-well plate in final volume of $150 \mu \mathrm{L}$. The plate reader TECAN Infinite M200 PRO (Switzerland) was used to read the fluorescence intensity with excitation and emission wavelengths of 340 and $450 \mathrm{~nm}$, respectively.

\subsubsection{Induction of drug resistance}

Initial MIC was taken as a reference point for experimental induction for drug resistance. Selected strains were tested by the serial passages in a medium supplemented with selected fluoroquinolones or new compounds below their active concentrations (0.5 MIC, 0.25 MIC). MIC values of compounds after each five, ten and fifteen passages were determined by a broth microdilution method (see above).

\subsubsection{In vitro cytotoxicity assays}

The cytotoxicity was determined by the standard colorimetric 3-(4,5-dimethylthiazol-2-yl)-2,5diphenyltetrazolium bromide (MTT) assay [69]. The assessment of cell population growth is based on the capability of living cells to reduce the yellow product MTT to a blue/purple product, formazan, by a reduction reaction occurring in the mitochondria catalysed by dehydrogenase enzyme. The adherent HEK-293 cells were seeded into 96-well plates $\left(2 \times 10^{4}\right.$ cells/well $)$ and cultured for $24 \mathrm{~h}$ at $37^{\circ} \mathrm{C}$ in a humidified atmosphere of $5 \% \mathrm{CO}_{2}$ allowing to attach. A solutions of the tested compounds in DMSO at desired concentrations were freshly prepared. The cells were then exposed to various concentrations of compounds ( $2 \mu \mathrm{L}$ of DMSO solution per $200 \mu \mathrm{L}$ of final volume). Cells untreated with compounds containing 0.5\% DMSO and medium without cells were used as negative control and blank control, respectively. After $72 \mathrm{~h}$ of the exposure to tested compounds $20 \mu \mathrm{L}$ MTT solution ( $4 \mathrm{mg} / \mathrm{mL}$ ) per well was added to each cultured medium, which was incubated for another $4 \mathrm{~h}$ in the $\mathrm{CO}_{2}$ incubator. The medium was removed to afford the resulting formazan crystals followed by dissolving in $75 \mu \mathrm{L}$ DMSO and the plates were shaken for $30 \mathrm{~min}$ at room temperature. The optical density (OD) of each well was measured at wavelength of $540 \mathrm{~nm}$ with a microplate reader and the 
percentage of cell growth was calculated. All samples were tested at two independent experiments, each done in triplicate.

\subsection{Molecular modeling}

\subsubsection{Ligand and protein preparation}

The structures of compounds were prepared in Online SMILES Translator and Structure File Generator [70] taking account the chirality on quaternary nitrogen atom and appropriate protonation states of compounds. The structures were converted into SMILES forms and diastereoisomers of chiral compounds were generated using FLIPPER tool in OMEGA software [71]. A library of conformers was generated with use of OMEGA using default settings, which resulted in a maximum of 200 conformers per ligand [72].

For docking with HYBRID software [73], proteins were prepared using MAKE RECEPTOR $[66,73,74]$. The grid box around the ligand bound in the crystal structure was generated automatically and was not adjusted, which resulted in grid box sizes of 4645 and $4431 \AA$ for $S$. aureus DNA gyrase and S. pneumoniae topoisomerase IV, respectively. For "Cavity detection" slow and effective "Molecular" method was used for detection of binding sites. Inner and outer contours of the grid box were also calculated automatically using "Balanced" settings for "Site Shape Potential" calculation, which again resulted in different outer contour sizes depending on the bound ligand, 1459 and $1262 \AA$ for S. aureus DNA gyrase and S. pneumoniae topoisomerase IV, respectively. The inner contours were disabled. Magnesium ion and Ser79 (S. aureus GyrA)/Ser84 (S. pneumoniae ParC) were used as constraints for docking calculations.

\subsubsection{Ligand docking}

The conjugates were docked using HYBRID [73,74]. Docking resolution was set to high; other settings were set as default. Ten docking solutions were inspected visually and the best ranked HYBRID-calculated conformation was used for analysis and representation.

\section{Author contributions}

JF designed the study. JF and JS wrote the manuscript. JF synthesized and characterized all the molecules reported. JF, AK, and KW tested the biological activity of the compounds and interpreted the results. KS, MM, SG-G, and AF designed and performed additional antibiofilm experiments. ŽS and TT performed DNA gyrase inhibition assays. DL carried out the cytotoxicity experiments. KC designed and evaluated lipophilicity experiments. JF performed docking experiments helped by TT. JS supervised the project. All authors discussed the results and commented on the manuscript.

Conflicts of interest: The authors declare no conflict of interest.

Acknowledgements: This work was supported by the National Science Centre, Poland [research grant number 2016/21/N/NZ7/03464]. We thank OpenEye Scientific Software, Santa Fe, NM., for 
free academic licenses for the use of their software. We thank to prof. Michał Obuchowski, Medical University of Gdańsk, for the opportunity to perform fluorescence microscopy experiments.

\section{References}

1. G.Y. Lesher, E.J. Froelich, M.D. Gruett, J.H. Bailey, R.P. Brundage. 1,8-Naphthyridine derivatives. A new class of chemotherapeutic agents. J. Med. Chem., 5 (1962), pp. 1063 1065

2. A.M. Emmerson, A.M. Jones. The quinolones: decades of development and use.

J. Antimicrob. Chemother., 51 (2003), pp. 13-20m Suppl. S1.

3. K. Drlica. Mechanism of fluoroquinolone action. Curr. Opin. Microbiol., 2 (1999), pp. 504508.

4. A. Wohlkonig, P.F. Chan, A. P Fosberry, P. Homes, J. Huang, M. Kranz, V.R. Leydon, N.D. Pearson, R.L. Perera, A.J. Shillings, M.N. Gwynn, B.D. Bax. Structural basis of quinolone inhibition of type IIA topoisomerases and target-mediated resistance. Nat. Struct. Mol. Biol., 17 (2010), pp. 1152-1153.

5. A.I. Cac, L.C. Tome, R. Dohrn, I.M. Marrucho. Protonation equilibria and lipophilicity of sarafloxacin. J. Chem. Eng. Data, 55 (2010), pp. 3160-3163.

6. S.V. Blokhina, A.V. Sharapova, M.,V. Ol'khovich, T.V. Volkova, G.L. Perlovich. Solubility, lipophilicity and membrane permeability of some fluoroquinolone antimicrobials. Eur. J. Pharm. Sci., 93 (2016), pp. 29-37.

7. G. El-Din, A.A. Abuo-Rahma, H.A. Sarhan, G.F.M. Gad. Design, synthesis, antibacterial activity and physicochemical parameters of novel N-4-piperazinyl derivatives of norfloxacin. Bioorg. Med. Chem., 17 (2009), pp. 3879-3886

8. E.Y. Ng, M. Trucksis, D.C. Hooper. Quinolone resistance mediated by norA: physiologic characterization and relationship to $\mathrm{flq} B$, a quinolone resistance locus on the Staphylococcus aureus chromosome. Antimicrob. Agents Chemother., 38 (1994), pp. 1345-1355.

9. H. Nikaido, D.G. Thanassi. Penetration of lipophilic agents with multiple protonation sites into bacterial cells: tetracyclines and fluoroquinolones as examples. Antimicrob. Agents Chemother., 37 (1993), pp. 1393-1399.

10. J.S. Chapman, N.H. Georgopapadakou. Routes of quinolone permeation in Escherichia coli, Antimicrob. Agents Chemother, 32 (1988), pp. 438-442

11. A.J.H. Marshall, L.J.V. Piddock. Interaction of divalent cations, quinolones and bacteria J. Antimicrob. Chemother., 34 (1994), pp. 465-483

12. R. O'Shea, H.E. Moser. Physicochemical properties of antibacterial compounds: implications for drug discovery. J. Med. Chem., 51 (2008), pp. 2871-2878

13. L. Feng, K. Lv, M. Liu, S. Wang, J. Zhao, X. You, S. Li, J. Cao, H. Guo. Synthesis and in vitro antibacterial activity of gemifloxacin derivatives containing a substituted benzyloxime moiety. Eur. J. Med. Chem., 55 (2012), pp. 125-136.

14. E. Pestov, J.J. Millichap, G.A. Noskin, L.R. Peterson. Intracellular targets of moxifloxacin: a comparison with other fluoroquinolonesm. J. Antimicrob. Chemother., 45 (2000), pp. 583590

15. R. Beyer, E. Pestova, J.J. Millichap, G.A. Noskin, L.R. Peterson. A convenient assay for estimating the possible involvement of efflux of fluoroquinolones by Streptococcus pneumoniae and Staphylococcus aureus: evidence for diminished moxifloxacin, sparfloxacin, and trovafloxacin efflux. Antimicrob. Agents Chemother., 44 (2000), pp. 798801. 
16. T.A. Davies, L.M. Kelly, G.A. Pankuch, K.L. Credito, M.R. Jacobs, P.C. Applebaum. Antipneumococal activities of gemifloxacin compared to those of nine other agents. Antimicrob. Agents Chemother., 44 (2000), pp. 304-310.

17. H. Lode. Potential interactions of the extended-spectrum fluoroquinolones with the CNS. Drug Saf., 21 (1999), pp. 123-135.

18. E. Chugunova, N. Akylbekov, A. Bulatova, N. Gavrilov, A. Voloshina, N. Kulik, V. Zobov, A. Dobrynin, V. Syakaev, A. Burilov. Synthesis and biological evaluation of novel structural hybrids of benzofuroxan derivatives and fluoroquinolones. Eur. J. Med. Chem., 116 (2016), pp. 165-172.

19. J. Liu, Z. Ren, L. Fan, J. Wei, X. Tang, X. Xu, D. Yang. Design, synthesis, biological evaluation, structure-activity relationship, and toxicity of clinafloxacin-azole conjugates as novel antitubercular agents. Bioorg. Med. Chem., 27 (2019), pp. 175-187.

20. G.-F. Zhang, X. Liu, S. Zhang, B. Pan, M.-L. Liu. Ciprofloxacin derivatives and their antibacterial activities. Eur. J. Med. Chem., 146 (2018), pp. 599-612.

21. Y.-L. Fan, J.-B. Wu, X.-W. Cheng, F.-Z. Zhang, L.-S. Feng. Fluoroquinolone derivatives and their anti-tubercular activities. Eur. J. Med. Chem., 146 (2018), pp. 554-563.

22. F. Gao, P. Wang, H. Yang, Q. Miao, L. Ma, G. Lu. Recent developments of quinolonebased derivatives and their activities against Escherichia coli. Eur. J. Med. Chem., 157 (2018), pp. 1223-1248.

23. J. Fedorowicz, J. Sączewski. Modifications of quinolones and fluoroquinolones: hybrid compounds and dual-action molecules. Monatsh Chem, 149 (2018), pp. 1199-1245.

24. X.-M. Chu, C. Wang, W. Liu, L.-L. Liang, K.-K. Gong, C.-Y. Zhao, K.-L. Sun. Quinoline and quinolone dimers and their biological activities: an overview. Eur. J. Med. Chem., 161 (2019), pp. 101-117.

25. Z. Xu, S.-J. Zhao, Z.-S. Lv, F. Gao, Y. Wang, F. Zhang, L. Bai, J.-L. Deng. Fluoroquinolone-isatin hybrids and their biological activities. Eur. J. Med. Chem., 162 (2019), pp. 396-406

26. F. Gao, X. Zhang, T. Wang, J. Xiao. Quinolone hybrids and their anti-cancer activities: an overview. Eur. J. Med. Chem., 165 (2019), pp. 59-79.

27. J. Zhang, S. Wang, Y. Ba, Z. Xu. 1,2,4-Triazole-quinoline/quinolone hybrids as potential anti-bacterial agents. Eur. J. Med. Chem., 174 (2019), pp. 1-8

28. V. Pokrovskaya, V. Belakhov, M. Hainrichson, S. Yaron, T. Baasov. Design, synthesis, and evaluation of novel fluoroquinolone-aminoglycoside hybrid antibiotics. J. Med. Chem., 52 (2009), pp. 2243-2254.

29. M.M. Škugor, V. Štimac, I. Palej, D. Lugaric', H.C. Paljetak, D. Filic, M. Modric, I. Dilovic, D. Gembarovski, S. Mutak, V.E. Haber, D.J. Holmes, Z. Ivezic-Schoenfeld, S. Alihodžić. Synthesis and biological activity of 4"-O-acyl derivatives of 14- and 15membered macrolides linked to $\omega$-quinolone-carboxylic unit. Bioorg. Med. Chem., 18 (2010), pp. 6547-6558.

30. M.F. Gordeev, C. Hackbarth, M.R. Barbachyn, L.S. Banitt, J.R. Gage, G.W. Luehr, M. Gomez, J. Trias, S.E. Morin, G.E. Zurenko, C.N. Parker, J.M. Evans, R.J. White, D.V. Patel. Novel oxazolidinone-quinolone hybrid antimicrobials. Bioorg. Med. Chem. Lett, 13 (2003), pp. 4213-4216.

31. H. Guo. Isatin derivatives and their anti-bacterial activities. Eur. J. Med. Chem., 164 (2019), pp. 678-688.

32. E. Chugunova, N. Akylbekov, A. Bulatova, N. Gavrilov, A. Voloshina, N. Kulik, V. Zobov, A. Dobrynin, V. Syakaev, A. Burilov. Synthesis and biological evaluation of novel structural hybrids of benzofuroxan derivatives and fluoroquinolones. Eur. J. Med. Chem., 116 (2016), pp. 165-172. 
33. M. Tischer, G. Pradel, K. Ohlsen, U. Holzgrabe. Quaternary ammonium salts and their antimicrobial potential: targets or nonspecific interactions? ChemMedChem, 7 (2012), pp. 22-31.

34. J. Sączewski, K. Hinc, M. Obuchowski, M. Gdaniec. The tandem mannich-electrophilic amination reaction: a versatile platform for fluorescent probing and labeling. Chem. Eur J., 19 (2013), pp. 11531-11535.

35. J. Saczewski, A. Kedzia, A. Jalińska. New derivatives of 4,6-dimethylisoxazolo[3,4-b] pyridin-3(1H)-one: synthesis, tautomerism, electronic structure and antibacterial activity Heterocycl. Commun. Now., 20 (2014), pp. 215-223.

36. J. Fedorowicz, J. Sączewski, Z. Drażba, P. Wiśniewska, M. Gdaniec, B. Wicher, G. Suwiński, A. Jalińska. Synthesis and fluorescence of dihydro-[1,2,4]triazolo[4,3-a]pyridin2-ium-carboxylates: an experimental and TD-DFT comparative study. Dyes Pigments, 161 (2019), pp. 347-359.

37. S. Terabe, K. Otsuka, K. Ichikawa, A. Tsuchiya, T. Ando. Electrokinetic separations with micellar solutions and open-tubular capillaries. Anal. Chem., 56 (1984), pp. 111-113.

38. J. Godyń, M. Hebda, A. Więckowska, K. Więckowski, B. Malawska, M. Bajda. Lipophilic properties of anti-Alzheimer's agents determined by micellar electrokinetic chromatography and reversed-phase thin-layer chromatography. Electrophoresis, 38 (2017), pp. 1268-1275.

39. M. Bajda, G. Chłoń-Rzepa, P. Żmudzki, A. Czopek, K. Stanisz-Wallis, K. Łątka, M. Pawłowski, A. Zagórska. Determination of ligand efficiency indices in a group of $7 \mathrm{H}-$ purine-2,6-dione derivatives with psychotropic activity using micellar electrokinetic chromatography. Electrophoresis, 39 (2018), pp. 2446-2453.

40. R. Gottardo, A. Bertaso, J. Pascali, D. Sorio, G. Musile, E. Trapani, C. Seri, G. Serpelloni, F. Tagliaro. Micellar electrokinetic chromatography: a new simple tool for the analysis of synthetic cannabinoids in herbal blends and for the rapid estimation of their $\log \mathrm{P}$ values. J. Chromatogr., A, 1267 (2012), pp. 198-205.

41. A. Taillardat-Bertschinger, P.-A. Carrupt, B. Testa. The relative partitioning of neutral and ionised compounds in sodium dodecyl sulfate micelles measured by micellar electrokinetic capillary chromatography. Eur. J. Pharm. Sci., 15 (2002), pp. 225-234.

42. A. Asadipour, M.H. Moshafi, L. Khosravani, S. Moghimi, E. Amou, L. Firoozpour, G. Ilbeigi, K. Beiki, E. Soleimani, A. Foroumadi. N-substituted piperazinyl sarafloxacin derivatives: synthesis and in vitro antibacterial evaluation. Daru, 26 (2018), pp. 199-207.

43. H.-G. Fu, Z.-W. Li, X.-X. Hu, S.-Y. Si, X.-F. You, S. Tang, Y.-X. Wang, D.-Q. Song. Synthesis and biological evaluation of quinoline derivatives as a novel class of broadspectrum antibacterial agents. Molecules, 24 (2019), p. 548.

44. K. Dileep, S. Polepalli, N. Jain, S.K. Buddana, R.S. Prakasham, M.S.R. Murty. Synthesis of novel tetrazole containing hybrid ciprofloxacin and pipemidic acid analogues and preliminary biological evaluation of their antibacterial and antiproliferative activity. Mol. Divers., 22 (2018), pp. 83-93.

45. H.A.E. Mohamed, H.F. Al-Shareef, Design, synthesis, anti-proliferative evaluation and cell cycle analysis of hybrid 2-quinolones a new class of hybrid 2-quinolone derivatives as anticancer agents, Anti-Cancer Agents Med. Chem. DOI : 10.2174/1871520619666190319142934

46. M. He, H. Xiao, Y. Zhou, P. Lu. Synthesis, characterization and antimicrobial activities of water-soluble amphiphilic copolymers containing ciprofloxacin and quaternary ammonium salts. J. Mater. Chem. B, 3 (2015), pp. 3704-3713.

47. J.W. Costerton, Z. Lewandowski, D.E. Caldwell, D.R. Korber, H.M. Lappin-Scott. Microbial biofilms. Annu. Rev. Microbiol., 49 (1995), pp. 711-745.

48. L. Hall-Stoodley, J.W. Costerton, P. Stoodley. Bacterial biofilms from natural environments to infectious diseases. Nat. Rev. Microbiol., 2 (2004), pp. 95-108. 
49. J.W. Costerton, L. Montanaro, C.R. ArciolaBiofilm in implant infections: its production and regulation. Int. J. Artif. Organs, 28 (2005), pp. 1062-106.

50. S.S. Branda, S.L. Vik, L. Friedman, R. Kolter. Biofilms: the matrix revisited. Trends Microbiol., 13 (2005), pp. 212-220.

51. F. Li, Z.G. Chai, M.N. Sun, F. Wang, S. Ma, L. Zhang, M. Fang, J.H. Chen. Anti-biofilm effect of dental adhesive with cationic monomer. J. Dent. Res., 88 (2009), pp. 372-376.

52. C. de la Fuente-Núñez, M.H. Cardoso, E. de Souza Cândido, O.L. Franco, R.E.W. Hancock. Synthetic antibiofilm peptides. BBA, 1858 (2016), pp. 1061-1069.

53. M.E. Skogman, P.M. Vuorela, A. Fallarero. A platform of anti-biofilm assays suited to the exploration of natural compound libraries. J. Vis. Exp., 118 (2016), Article e54829.

54. J.M. Munita, C.A. Arias. Mechanisms of antibiotic resistance. Microbiol. Spectr., 4 (2016) VMBF-0016-2015

55. B. Marquez. Bacterial efflux systems and efflux pumps inhibitors. Biochimie, 87 (2005), pp. 1137-1147.

56. H. NikaidoMultidrug efflux pumps of gram-negative bacteria. J. Bacteriol., 178 (1996), pp. 5853-5859.

57. W. Phetsang, R. Pelingon, M.S. Butler, S. Kc, M.E. Pitt, G. Kaeslin, M.A. Cooper, M.A.T. Blaskovich. Fluorescent trimethoprim conjugate probes to assess drug accumulation in wild type and mutant Escherichia coli. ACS Infect. Dis., 2 (2016), pp. 688-701.

58. O. Lomovskaya, M.S. Warren, A. Lee, J. Galazzo, R. Fronko, M. Lee, J. Blais, D. Cho, S. Chamberland, T. Renau, R. Leger, S. Hecker, W. Watkins, K. Hoshino, H. Ishida, V.J. Lee. Identification and characterization of inhibitors of multidrug resistance efflux pumps in Pseudomonas aeruginosa: novel agents for combination therapy. Antimicrob. Agents Chemother., 45 (2001), pp. 105-116.

59. T.D. Davis, C.J. Gerry, D.S. Tan. General platform for systematic quantitative evaluation of small-molecule permeability in bacteria. ACS Chem. Biol., 9 (2014), pp. 2535-2544.

60. H. Cai, K. Rose, L.-H. Liang, S. Dunham, C. Stover. Development of a liquid chromatography/mass spectrometry-based drug accumulation assay in Pseudomonas aeruginosa. Anal. Biochem., 385 (2009), pp. 321-325.

61. M. Ghoul, M. Pommepuy, A. Moillo-Batt, M. Cormier. Effect of carbonyl cyanide mchlorophenylhydrazone on Escherichia coli halotolerance. Appl. Environ. Microbiol., 55 (1989), pp. 1040-1043.

62. T. Mosmann. Rapid colorimetric assay for cellular growth and survival: application to proliferation and cytotoxicity assays. J. Immunol. Methods, 65 (1983), pp. 55-63.

63. N. Yang, X. Liu, D. Teng. Antibacterial and detoxifying activity of NZ17074 analogues with multi-layers of selective antimicrobial actions against Escherichia coli and Salmonella enteritidis. Sci. Rep., 7 (2017), p. 3392.

64. P.F. Chan, V. Srikannathasan, J. Huang, H. Cui, A.P. Fosberry, M. Gu, M.M. Hann, M. Hibbs, P. Homes, K. Ingraham, J. Pizzollo, C. Shen, A.J. Shillings, C.E. Spitzfaden, R. Tanner, A.J. Theobald, R.A. Stavenger, B.D. Bax, M.N. Gwynn. Structural basis of DNA gyrase inhibition by antibacterial QPT-1, anticancer drug etoposide and moxifloxacin. Nat. Commun., 6 (2015), p. 10048.

65. D.A. Veselkov, I. Laponogov, X.-S. Pan, J. Selvarajah, G.B. Skamrova, A. Branstrom, J. Narasimhan, J.V.N.V. Prasad, L.M. Fisher, M.R. Sanderson. Structure of a quinolonestabilized cleavage complex of topoisomerase IV from Klebsiella pneumoniae and comparison with a related Streptococcus pneumoniae complex. Acta Crystallogr D Struct Biol, 72 (2016), pp. 488-496.

66. Release 3.2.0.2, OpenEye Scientific Software, Inc., Santa Fe, NM, USA; www.eyesopen.com. 
67. Methods for Dilution Antimicrobial Susceptibility Tests for Bacteria that Grow Aerobically; Approved Standard-Ninth Edition CLSI. M07-A9 Vol. vol. 32 (2012) 2

68. Method for determination of Minimum Inhibitory Concentration (MIC) by broth dilution of fermentative yeast. EUCAST Discussion Document E. Dis, 7 (2002), p. 1

69. F. Denizot, R. Lang. Rapid colorimetric assay for cell growth and survival: modifications to the tetrazolium dye procedure giving improved sensitivity and reliability. J. Immunol. Methods, 89 (1986), pp. 271-277.

70. https://cactus.nci.nih.gov/translate/

71. Release 2.5.1.4, OpenEye Scientific Software, Inc., Santa Fe, NM, USA.

72. P.C. Hawkins, A.G. Skillman, G.L. Warren, B.A. Ellingson, M.T. Stahl. Conformer generation with OMEGA: algorithm and validation using high quality structures from the Protein Databank and Cambridge Structural Database. J. Chem. Inf. Model., 50 (2010), pp. 572-584.

73. M.R. McGann, H.R. Almond, A. Nicholls, J.A. Grant, F.K. Brown FK. Gaussian docking functions. Biopolymers, 68 (2003), pp. 76-90.

74. G.B. McGaughey, R.P. Sheridan, C.I. Bayly, J.C. Culberson, C. Kreatsoulas, S. Lindsley, V. Maiorov, J.F. Truchon, W.D. Cornell WD. Comparison of topological, shape, and docking methods in virtual screening. J. Chem. Inf. Model., 47 (2007), pp. 1504-1519. 